\title{
Critical storm thresholds for significant morphological changes and damage along the Emilia-Romagna coastline, Italy
}

\author{
Clara Armaroli ${ }^{\text {a, }}{ }^{\text {, Paolo Ciavola }}{ }^{\text {a,* }}$, Luisa Perini ${ }^{\text {b }}$, Lorenzo Calabrese ${ }^{\text {b }}$, Samantha Lorito ${ }^{\text {, }}$ \\ Andrea Valentini ${ }^{\text {c }}$, Marinella Masina ${ }^{\mathrm{a}, 1}$ \\ a Dipartimento di Scienze della Terra, Università di Ferrara, Via Saragat 1, 44100 Ferrara, Italy \\ b Servizio Geologico, Sismico e dei Suoli, Regione Emilia-Romagna, Viale Della Fiera 8, 40127 Bologna, Italy \\ c Arpa, Servizio IdroMeteoClima, Viale Silvani 6, 40122 Bologna, Italy
}

\section{A R T I C L E I N F O}

\section{Article history:}

Received 28 June 2010

Received in revised form 2 September 2011

Accepted 5 September 2011

Available online 10 September 2011

\section{Keywords:}

Dune

Coastal structures

Flooding

Vulnerability

Warning system

\begin{abstract}
A B S T R A C T
The definition of storm morphological thresholds along the coast of the Emilia-Romagna Region strictly depends on its configuration and variability. The region is located in northern Italy, facing the Adriatic Sea. The coastline is characterised by very different levels of economic development, ranging from natural zones with dunes to highly developed stretches protected by breakwaters and groynes. The Integrated Coastal Zone Management effort is mainly concentrated on preserving urban areas that generate significant income for the regional economy. Natural areas, while small in comparison to the urbanised zone, are important for environment preservation. Because of such a multiplicity of issues at stake, it was decided to produce two different thresholds: one for the morphological impact on natural sectors and another for inundation and damage to structures along urbanised zones.

The "forcing" component of the threshold definition for natural areas was calculated by summing the effects of surge + tide + waves (run-up elevation) to find the Maximum Water Level (MWL) reached by the sea during one, ten and one-hundred year storm return periods. For urbanised zones, historical storm information was collected starting from the 1960s in order to identify the forcing conditions causing real damages. Each storm was classified in terms of wave height, period, direction and surge level. Morphological information were obtained from Lidar flights performed in 2003 and 2004 and from direct surveys undertaken in September 2008 and February 2009 as part of the monitoring programme for the MICORE Project.

The computed MWL for each return period was then compared to beach elevations along natural areas in order to calculate the Dune Stability Factor (DSF), an index that accounts for the eroded sediment volume above the MWL during a storm. Based on analysis along 41 profile lines at a $500 \mathrm{~m}$ spacing, it was found that the 1 -in1 year return period wave height +1 -in- 1 year return period surge are able to erode and/or overwash $2 / 3$ of the dunes.

The historical storm hydrodynamic information was used to estimate which wave and surge conditions are able to inundate at least $2 / 3$ of the beach profiles. The MWL was again compared to beach elevations, this time along 63 anthropogenic profiles spaced $500 \mathrm{~m}$ apart (or $1 / 3$ of the urbanised coastline). It was found that a wave heights $>=2 \mathrm{~m}$ and surge + tide levels $>=0.7 \mathrm{~m}$ are able to flood between $18 \%$ and $36 \%$ of the built-up coast. The defined thresholds are related to the present coastal characteristics and are not "static", meaning that they are likely to change according to future evolution of the coastline. They are very important because they can be used as thresholds to issue warnings and alert the Civil Protection. Moreover they are the first thresholds defined for the Emilia-Romagna coastline and will be used as starting values to generate "dynamic" thresholds based on numerical model predictions of morphological change for a given wave and surge level.
\end{abstract}

(c) 2011 Elsevier B.V. All rights reserved.

\footnotetext{
* Corresponding author. Tel.: + 390532974739 ; fax: + 390532974767. E-mail addresses: rmrclr@unife.it (C. Armaroli), cvp@unife.it (P. Ciavola), LPerini@regione.emilia-romagna.it (L. Perini), LCalabrese@regione.emilia-romagna.it (L. Calabrese), SLorito@regione.emilia-romagna.it (S. Lorito), avalentini@arpa.emr.it (A. Valentini), rmrclr@unife.it (M. Masina).

1 Tel.: + 390532974739 ; fax: + 390532974767.
}

\section{Introduction}

The evaluation of inundation risk generated by marine storm events along coastal areas is becoming increasingly important worldwide in terms of coastal planning and civil protection. In the context of climate change, governments of many countries around the world are facing unsustainable costs in restoring areas affected by extreme storms (Pompe and Rinehart, 2008) as they have to cope 
with the consequences of environmental and social disasters (e.g. Hurricane Katrina, New Orleans).

The EU Directive (2007/60/EC) states that each EU country will by 2015 have to produce regulations and laws to manage natural risks (e.g. landslides, river floods, coastal erosion and inundation) that include the vulnerability of coastal areas. EU countries will have to create new civil protection schemes able to both counteract climate change and prevent risky conditions for the population, while at the same time preserving human and natural assets. An historical "storm" database is one of the instruments indicated inside the EU Directive as a means of assessing the areas that are most frequently impacted by storms. Regarding Italy, there are already historical databases on seismic, hydrogeological and hydraulic events (Cipolla et al., 1999; Guzzetti, 2000; Guzzetti et al., 2002). The collection and analysis of information of historical marine storms in Italy however has never been conducted.

As a result of the increasing interest worldwide in environmental issues and in the significant effects of storms along coastlines, a specific European project MICORE (Morphological Impact and COastal Risks induced by Extreme storm events) has been financed within the VII Framework Programme (www.micore.eu). MICORE intends to evaluate the risks from coastal erosion and flooding, with its final goal being to create warning systems to prevent disasters for the population living and working along coastlines and to preserve human and natural assets within close proximity to the sea. This approach is no longer unique to Europe - authorities on the west coast of the USA are developing comparable warning systems based on ensembles of regional wave models and local morphological models (Barnard et al., 2009).

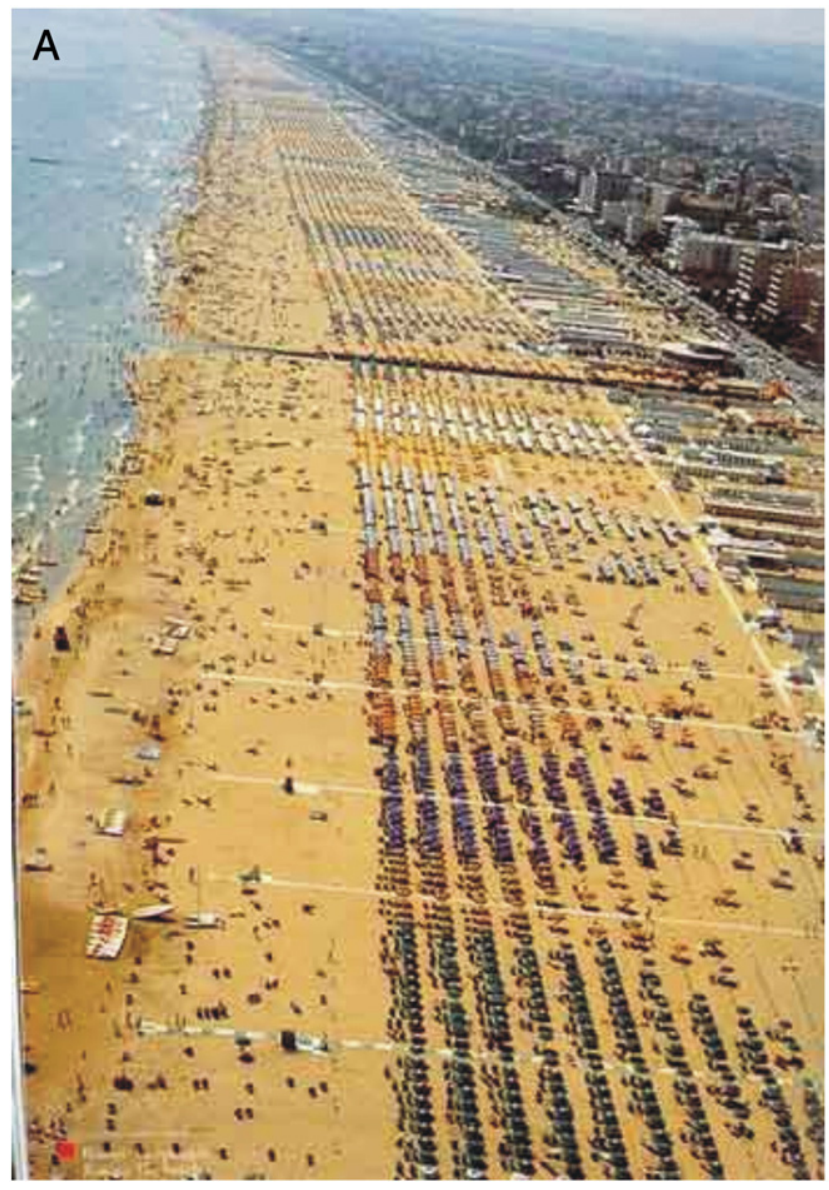

In order to produce reliable warning systems and optimise their speed in obtaining coastal erosion forecasts, critical thresholds for the forcing agents (e.g. waves, current, tides) must first be identified and the factors specific to the particular coastal segment (e.g. wave exposure, sedimentological/geomorphological characteristics, presence of coastal structures etc.) accounted for. Most of the work present in the literature deals with the impact of hurricanes, for recent papers see Wang et al. (2006), Robertson et al. (2007), Stockdon et al. (2007), Houser and Hamilton (2009) and Plant et al. (2010). Notable exceptions that concentrate on storms are the "beach erosion potential" of Zhang et al. (2001) and the seminal work of Sallenger (2000) in producing a storm impact scale specific for dunes and barrier-islands. On a strategic level, future coastal planning will have to take into account the occurrence of flood events and erosion, so that many authors have mapped maximum run-up levels which can be useful to delimit set-back lines (Benavente et al., 2006; Ferreira et al., 2006; Ciavola et al., 2007a).

The application of storm indexes to highly developed Mediterranean coastlines remains very limited and largely confined to the Western Mediterranean (Mendoza and Jimenez, 2004, 2006). Recently Jiménez et al. (2009) concluded that both Mediterranean and northern Adriatic beaches have common vulnerabilities, a result of the low beachface gradients and exposure to storm inundation in both regions. Despite the high level of occupation of Italian beaches, the issue of storm damage to developed coastlines has been neglected.

The definition of storm thresholds at a regional scale for the EmiliaRomagna coast must account for its peculiar configuration and level of human development. The coastline is characterised by very different levels of modification, ranging from natural zones with dunes to highly developed stretches of intense development. These developed stretches

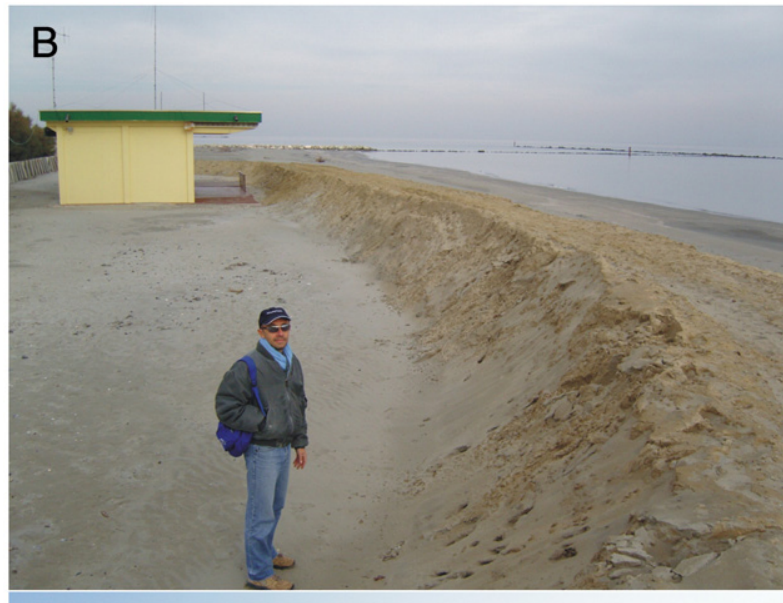

C

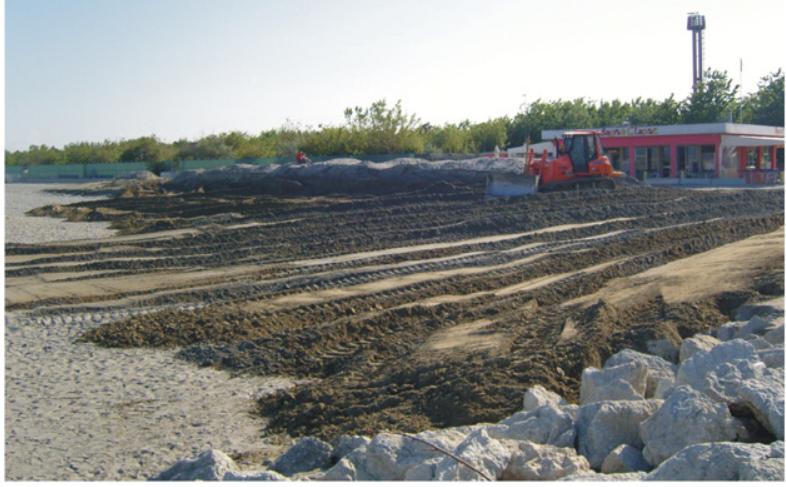

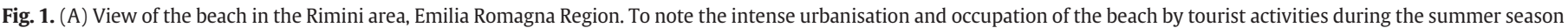

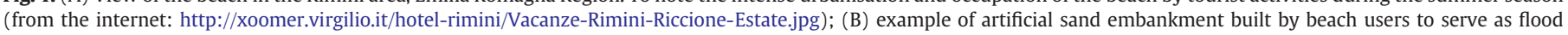
protection (November 2008); (C) the sand is bulldozed back to the lower beach at the beginning of the bathing season (May 2008). This creates unnatural beach slopes. 
consist of beach huts (known locally as "bagni") backed by buildings extending hundreds of metres inland without interruption. Between May and September, thousands of tourists occupy the beach with lines of umbrellas and sun chairs down to the intertidal area (Fig. 1A). Coastal protection is provided by groynes and breakwaters offshore and by artificial sand embankments (known as "winter dunes") that are normally constructed before the winter season by moving sand accumulated in front of beach huts to the upper shoreface as a means of preventing inundation and damage from strong winter storms (Fig. 1B). In spring, before the beginning of the summer/tourist season, the sand is redistributed along the profile to gain additional space (in a cross-shore direction) for beach users (Fig. 1C). Because of these interventions, the beach profile can be considered completely artificial for the majority of the time.

The Integrated Coastal Zone Management (ICZM hereafter) effort in this region is mainly concentrated on preserving the areas that generate a significant income for the regional economy. Natural areas meanwhile are important for environmental preservation and even for a new "green" tourist strategy. While regional authorities regularly collect information on damage to human infrastructure, the effects of storms on natural dunes are largely ignored. It is important to underline that in comparison to the urbanised zones, which make up $93 \mathrm{~km}$ (or 71\%) of the $130 \mathrm{~km}$ length of examined coastline, the extent of natural coastline is minimal.

This paper focuses on the definition of morphological and physical thresholds based on the risk definition along the Emilia-Romagna coastline. Because of the multiplicity of coastal issues at stake in this region (high urbanisation in some areas and presence of preserved ecological habitats in others), it was decided to produce two different thresholds: one for the morphological impact on natural sectors and another for inundation and damage to structures along urbanised zones. To the knowledge of the authors, no previous papers have proposed indexes for damage in areas protected by coastal structures, neither for Italy nor for other coastlines worldwide. Most storm indexes are developed for the impact of catastrophic events like hurricanes or typhoons and deal with open coastlines. However, for highly urbanised coastlines like the Mediterranean ones the impact of more frequent storms has important socio-economic consequences. We believe that the current paper, being based on a dataset collected on a highly protected coastline with a high diversity of coastal defence structures can be used by coastal managers trying to propose adaptation strategies in the context of climate change scenarios.

\section{Study area}

The prevalent wave direction along the Emilia-Romagna coastline is from the east, while the most intense storms are from the ENE (known as the "Bora wind"). This is due to the orientation of the coast (Fig. 2A), which is partially sheltered from south-easterly winds (or "Sirocco") by the Conero headland (The Marche Region). The most energetic storms are generated by the Bora, which is a strong, cold, gusty wind that blows intermittently from the northeast mainly during the winter. The Bora jets have a strong influence on the wave climate and current circulation in the entire northern Adriatic (Signell et al., 2010).

Wave data are currently measured by a buoy located in front of the town of Cesenatico. Tide data are measured by a tide gauge located, inside Ravenna harbour. The wave height is generally low with $91 \%$ of occurrences below $1.25 \mathrm{~m}$ (Fig. 2B). Most storms have a duration of less than $24 \mathrm{~h}$ and a maximum significant wave height of about $2.5 \mathrm{~m}$. The typical meteorological synoptic configuration for the generation of extreme events is caused by rotational wind systems located over the northern Adriatic. First the Sirocco wind blows from the SE for several hours before the ENE (Bora) starts, leading to the generation of large waves. This kind of meteorological phenomenon is known locally as "dark Bora" (Bora scura). Its main characteristic is the association during the same event of high surge levels (barometric component together with the water piling along the coast produced by SE winds) with high waves driven by ENE winds generated by the wind rotational phenomenon described above. During these storms considerable offshore waves can occur, as the 1-in-1-year return period significant wave height is $3.3 \mathrm{~m}$, while the 10 -yr one reaches $4.7 \mathrm{~m}$.

The area is microtidal (mean neap tidal range is $30-40 \mathrm{~cm}$; mean spring tidal range is $80-90 \mathrm{~cm}$ ) with both diurnal and semidiurnal components. When SE winds blow, significant surge levels are reached, which are able to double the maximum tidal elevation. Relative SeaLevel Rise is higher than the global eustatic component due to subsidence that affects many sites along this coastline (Houtenbos et al., 2005) The main factors causing land lowering are extractions of water (especially during the summer season due to massive tourist presence), oil and gas.

\subsection{The regional coastline}

Coastal development in Emilia-Romagna primarily took place in the second half the XX century (Lorito et al., 2010). From a geomorphological viewpoint the dominant landscape is a sandy beach of average width $70 \mathrm{~m}$ that is generally protected (except in some cases in Ferrara and Ravenna provinces) by offshore breakwaters. The main characteristics of the built-up/protected coastline are: very dissipative beaches (surf scaling parameters- $\xi_{0}<0.3$ ) with a mean slope $(\tan \beta)$ of 0.03 ; low elevation above MSL (mean max topographic height is $1.45 \mathrm{~m}$ above MSL); fine sediments; absence of subtidal bars; absence of dunes; occasional presence of intertidal bars and beach cusps (Sedrati et al., 2009).

In the northern and central part of the Emilia-Romagna region the coastal landscape is flat, where the only relief is represented by old beach ridges or artificial embankments. In the southern part the coastal corridor is completely urbanised. Elevations in this region are often at or even below MSL. Dune fields along this coastline are rare, a study based on a 2005 aerial flight by Perini and Calabrese (2010) quantifies that only $28 \%$ of the $130 \mathrm{~km}$ long coastline has dunes, with the longest and uninterrupted stretches in the provinces of Ravenna and Ferrara. Over half of these are heavily stabilised dunes, with the remaining ones being semi-stabilised and only $9 \%$ active foredunes. Dune crests have on average an elevation between 1.5 and $3 \mathrm{~m}$ above MSL, except in the Ferrara province, where they can reach 5-6 $\mathrm{m}$ above MSL.

It is important to point out that the whole region, as many others along Italian coastlines, is currently experiencing a sediment deficit in the littoral budget - a result of decreases in fluvial sediment transport caused by demand for aggregates and stabilisation of slopes from the 1970s onwards. The unprecedented coastal development in the last 50 years has exacerbated this problem, with coastal dune ridges replaced with bathing structures such as those indicated in Fig. 1A. Exposure to sea ingression has therefore increased and flood defence schemes (e.g. parallel groynes, breakwaters) have been built in the hope that beach retreat would cease.

The brief historical developments cited above become clear by comparing shorelines mapped on 1943, 1982 and 2005 aerial photographs (Fig. 3). According to Calabrese and Lorito (2010), 80\% of the coastline in 1943 was in a natural state. A period of intense construction throughout the 1970 s however meant that by 1982 , only $50 \%$ of the coastline remained largely undeveloped. The areas that were in the most critical state at that time were in the northern and central parts, where river mouths were being eroded substantially. Dykes for flood protection were subsequently built, following disastrous floods in Ferrara and Ravenna provinces. The accretion trends presented in Fig. 3 should be taken with care, since these areas often correspond to jetties and/or breakwaters in front of which alongshoremoving sediment accumulates. The accretion is in fact very weak and very much relies on the maintenance of these structures. It could be 
A

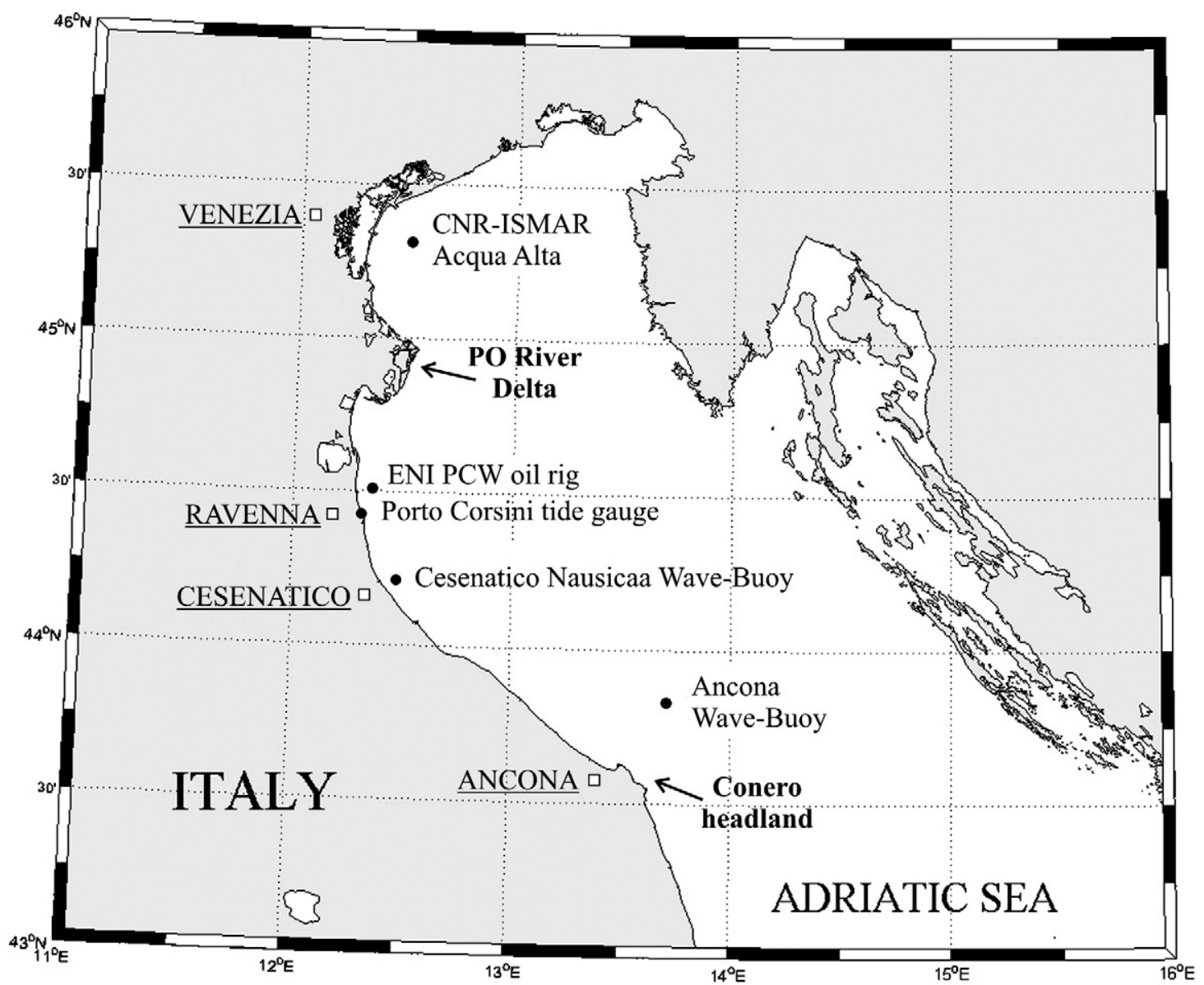

B

Cesenatico_Nausicaa_Wave-Buoy

Significant Wave Height (SWH, m)

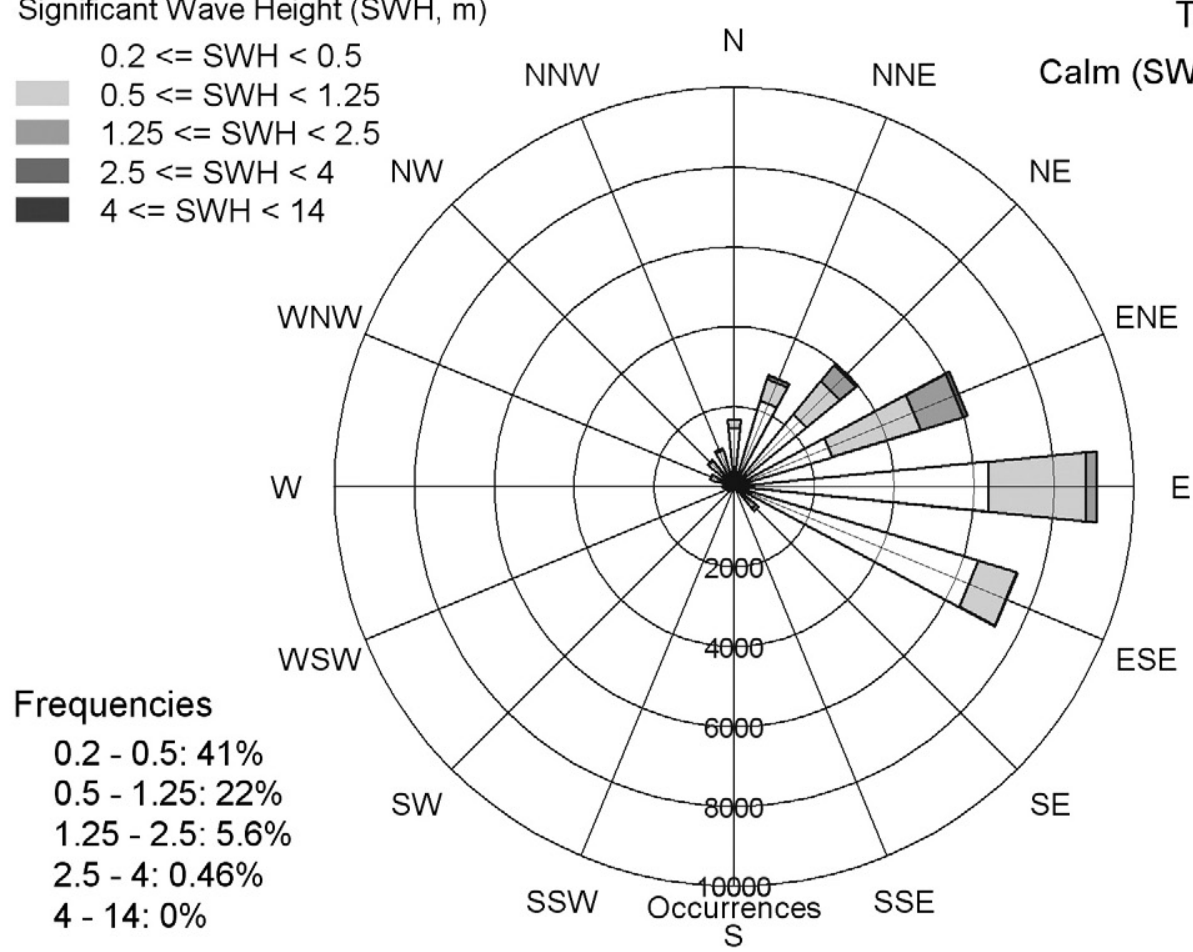

Total data: 35293 


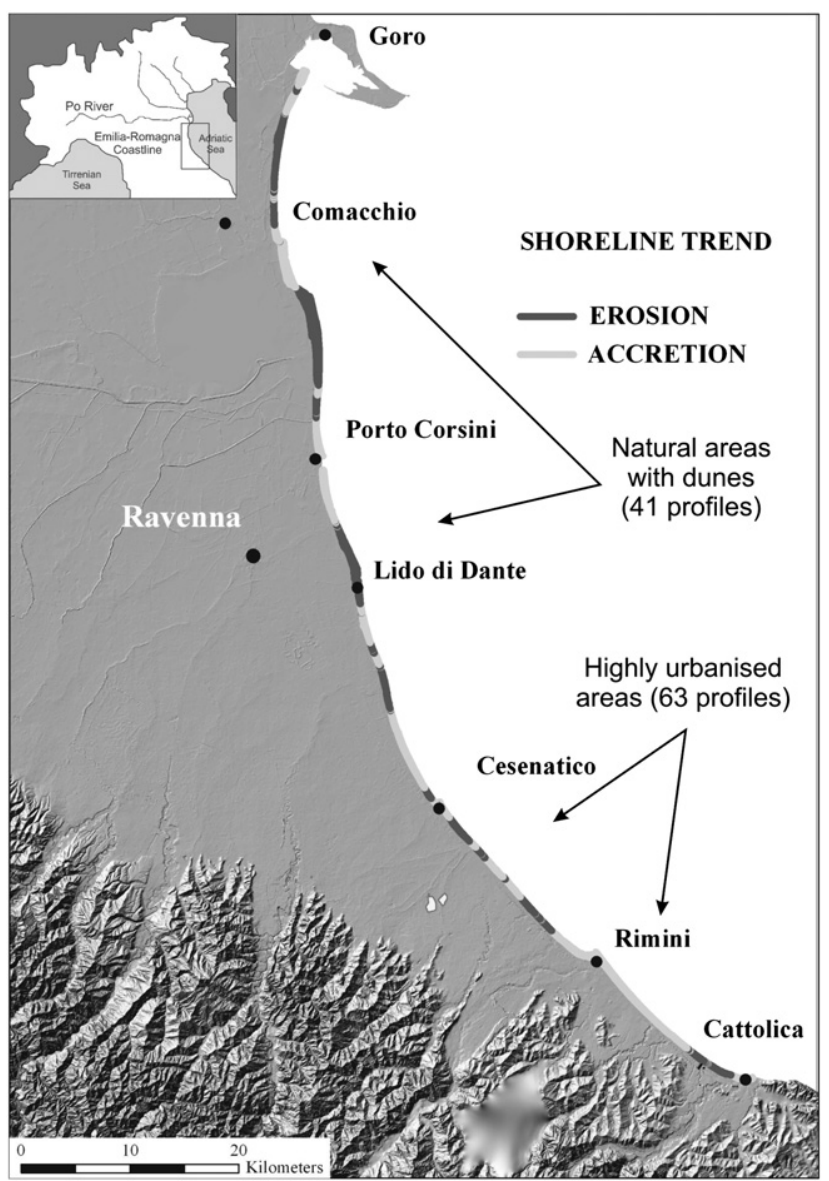

Fig. 3. Shoreline trends at regional scale obtained comparing 1943 aerial photographs with a 2005 flight. The map can be considered representative of the impact of post WWII coastal development. The map also shows the location of profiles used to test the DSF as an indicator of morphological storm impact on the dune system (Ferrara and Ravenna Provinces) and to define the thresholds for inundation and damage to structures along urbanised areas using recorded information derived from regional reports.

quite correctly stated that in the last 30 years the Emilia-Romagna coastline is in a "frozen state". In fact the majority of the coast shows rates of erosion/accretion between -1 and $+1 \mathrm{~m} / \mathrm{yr}$ (Fig. 3). As explained above, between 1943 and 1982 there are several areas that reveal strong erosion and significant accretion (more than $\pm 5 \mathrm{~m}$, e.g. Lido di Dante and Comacchio); in contrast between 1982 and 2005 the rates decrease and become close to zero, except for the zones near Comacchio. Note that with a reduced coastal sediment budget by rivers and with so many obstacles for longshore drift, the coast has remained in its position essentially because of human intervention, which since the late 1990s has included widespread beach replenishment.

\subsection{Lido di Dante-Lido di Classe, Ravenna-the MICORE case study site}

The specific case study site chosen for intensive monitoring during the MICORE project was the Lido di Dante-Lido di Classe area, consisting of $8 \mathrm{~km}$ of sandy beaches and dunes along the coastline of Ravenna Province (Fig. 4). The area is partly located in a natural park and partly exploited for tourism and oil extraction activities. Subsidence at the study site is in the order of $10-15 \mathrm{~mm} / \mathrm{yr}$ (Teatini et al., 2005). There are three river mouths. One represents the northern boundary of the study site (Fiumi Uniti). Here the river mouth resembles an estuary and is bounded at the northern edge by a dyke to protect agricultural land. The southern bank is natural and borders the village of Lido di
Dante. Part of the site is protected by breakwaters and groynes and is the subject of beach replenishment schemes.

The second river mouth (Bevano) is located in the central part, inside the natural park. Here the river has very limited water discharge. Previous studies described its mouth as a small tidal inlet (Gardelli et al., 2007). The third river mouth (Fiume Savio) represents the southern edge of the studied coastal segment and has the largest outflow of the area. At Lido di Dante an Argus station has been active since 2003, installed within the European Project Coastview (EVK3-CT-200100054) to monitor $3 \mathrm{~km}$ of coastline (both natural and defended). For further details see Armaroli et al. (2007a).

The submerged beach, meaning the area from the outer bar in the natural area and between the low tide elevation and the breakwaters in the urbanised zone down to the closure depth, is generally composed of fine sand, while the beachface is occupied by fine to medium sands. The intertidal beach slope varies significantly along the $8 \mathrm{~km}$ of coastline, ranging from mild $(2.5 \%)$ to steep (14\%) values. Steep values are representative of areas next to coastal defence structures (i.e. groynes) while lower values are associated with the natural area inside the park with dunes and longshore bars. The mean submerged beach slope along the entire region is 3\% (from the MSL to the outer bar foot). The slope of the beach from the outer bar to the closure depth is very mild ( $0.2 \%)$. According to the morphodynamic classification of Wright and Short (1984), the beaches of the study site are classified as intermediate type LBT, RBB and TBR. The relative tidal range (RTR) is 1.66 and $\Omega$ (Dean's parameter) is 3.21 , which according to the classification of Masselink and Short (1993) suggests that the beaches should be classified as "barred".

Intertidal bars (such as swash bars) are often observed within both the urban and natural areas. Submerged longshore bars are present only in the area free from structures (almost $4 \mathrm{~km}$ of coastline). Previous studies used the Argus system to monitor bar dynamics up to $2 \mathrm{~km}$ away from the breakwaters that protect the Lido di Dante village (Fig. 4). The results of these studies show that the inner and outer bar system is very dynamic (Armaroli et al., 2007a; Armaroli and Ciavola, 2011) and that the beach where bars are present is stable and not eroding.

\section{Methods}

The general methodology to identify the thresholds for morphological change and for coastal erosion/flooding consisted of comparing land elevation along the coastline (topography) with marine water levels (surge + tide) and offshore wave heights. The offshore wave height was used to compute run-up/set-up on the beach using measured beach profiles.

The methodology described above was used to create a vulnerability classification and to define thresholds for erosion/flooding for two different "environments": i) the natural part of the studied coastline characterised by the presence of dunes and absence of infrastructures; and ii) the urbanised part of the coast.

The following paragraphs will describe in detail the methodology used for each environment and the input information on the forcing parameters used to compare the topographic beach elevation with the hydrodynamic data used to compute the MWL.

\subsection{Wave and tide time series}

Publicly-available buoy observations in Italy are provided by ISPRA (formerly APAT) through the National Wave Buoy Network (RON - Rete Ondametrica Nazionale - Arena et al., 2001). Along the northern Adriatic Sea there are two buoys (Fig. 2A), one located offshore of Ancona (43.83 N; $13.71 \mathrm{E}$, Table 1) and the other located in front of the Po Delta (Punta della Maestra, $44.97 \mathrm{~N} ; 12.63 \mathrm{E}$, Table 1). The former has the longest wave record (1999-2006), but is quite far (about $100 \mathrm{~km}$ ) from the Emilia-Romagna coast. It ceased 


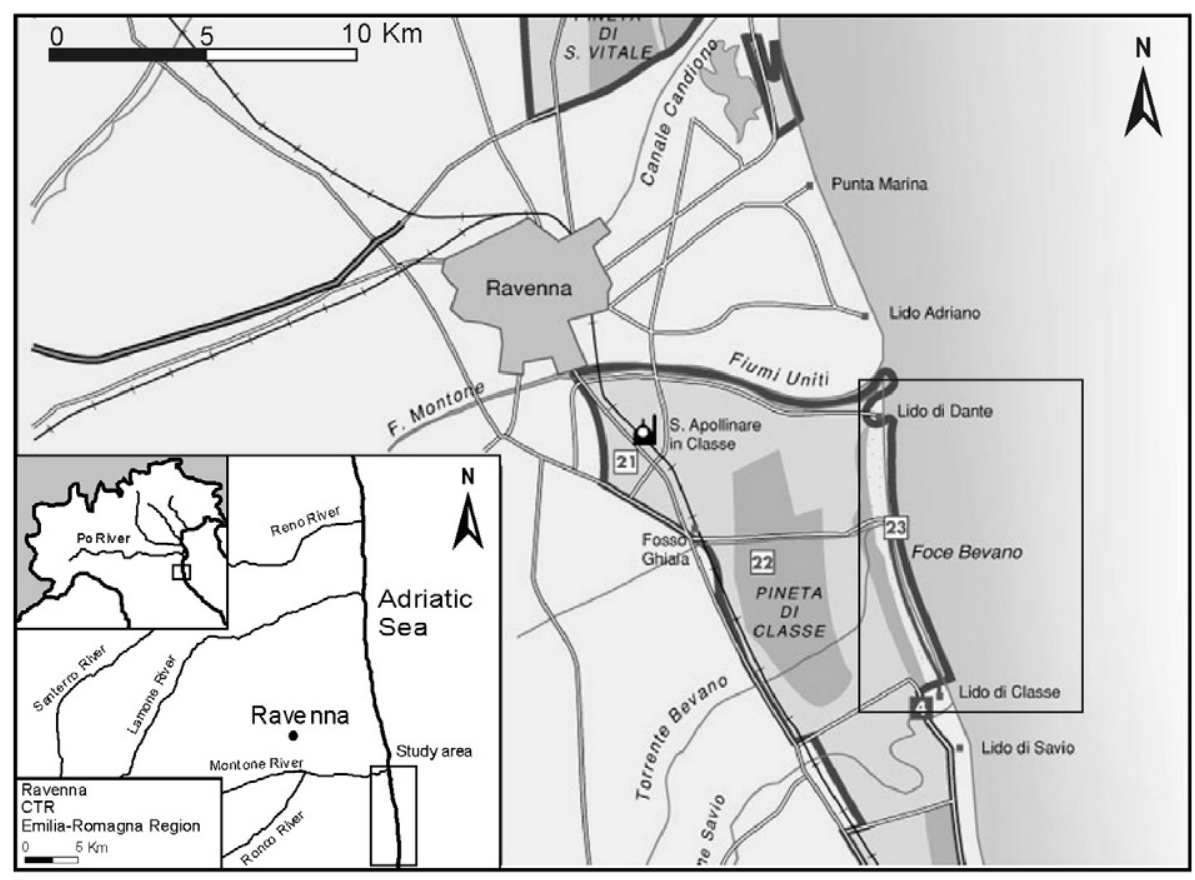

Fig. 4. Lido di Dante-Lido di Classe location.

working in May 2006 and was reinstalled at the end of 2009. The Punta della Maestra buoy meanwhile has a very short and incomplete dataset. It was removed in November 2004 after only one year of observations. All buoys provided directional measurements every $30 \mathrm{~min}$.

Because of the limited duration of the RON dataset, other nondirectional wave measurements were used to extend the database back to the 1990s, (Table 1 and Fig. 2B). The longest time series comes from a wave gauge located on the PCW oil-rig, owned by the oil company ENI and located in front of Ravenna. Additional data are available from the Acqua-Alta oceanographic platform of the CNR-ISMAR (Italian National Research Council) offshore of Venice. Currently the only on-line source of data for the Emilia-Romagna Region is the Nausicaa wave buoy, located in front of Cesenatico and maintained by ARPA (Emilia-Romagna Environment Agency).

As done by previous authors (e.g. Armaroli et al., 2007a) data from Ancona were transposed to the area in front of Ravenna by applying the transposition methods based on the ratio between effective fetches. Data measured by CNR-ISMAR in Venice as well as those measured on the ENI-PCW oil rig could not be manipulated as they are non-directional.

Finally, due to some gaps in observations in the Ancona and Cesenatico datasets and due to the complete absence of wave measurements in the period 2005-2007, missing periods were filled using wave forecasts modelled by ARPA-SIMC. The forecasts were extracted from the computational grid described below in the same position as the Nausicaa buoy, in front of Cesenatico. These modelled data were obtained using the operational Sea-State forecasting system of ARPASIMC, MEDITARE (Valentini et al., 2007). This forecasting system consists of a sequence of nested runs that start from a coarse run over the whole Mediterranean Sea at a resolution of about $25 \mathrm{~km}$. The run produces the boundary conditions for the following step that generates information over the whole Italian coastal domain at a resolution of $8 \mathrm{~km}$. The successive steps are designed to achieve higher resolutions (about $800 \mathrm{~m}$ ) suitable for small coastal domains such as the Emilia-Romagna coast using the same nesting technique. Operationally the chain provides one run each day at 00 UTC and a forecast for the next $72 \mathrm{~h}$ with hourly outputs. Data are available since 2004.

\subsection{Forcing input: marine storm identification and isolation}

In the literature there is not a unique and standardised definition for "marine storm" because many methods can be applied to isolate an extreme event from a wave dataset. Each method differs from the others for the variables used for the analysis and how they are interrelated. Also, the specific geographical configurations of the basin where sea storms have to be identified play an important role.

For Italian coastlines there are two methods that were previously developed by local oceanographers and engineers. The first (Bertotti et al., 1996) identifies a marine storm as a time series of sea states characterised by a maximum significant wave height higher than $2 \mathrm{~m}$. The time interval between two subsequent storm peaks should be at least $24 \mathrm{~h}$. Finally, to separate two successive peaks, the significant wave height should become lower than $50 \%$ of the first peak. The

Table 1

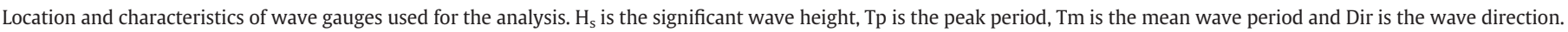

\begin{tabular}{|c|c|c|c|c|c|c|}
\hline Station & Latitude N & Longitude $\mathrm{E}$ & Water depth (m) & Variables & Frequency of acquisition (hours) & Period of observation \\
\hline Venezia CNR rig & $45^{\circ} 18.8^{\prime}$ & $12^{\circ} 30.5^{\prime}$ & 16 & $\mathrm{H}_{\mathrm{s}}, \mathrm{T}_{\mathrm{p}}, \mathrm{T}_{\mathrm{m}}$ & 3 & 2001-2006 \\
\hline Ravenna ENI PCW rig & $44^{\circ} 30.7^{\prime}$ & $12^{\circ} 21.6^{\prime}$ & 12.5 & $\mathrm{H}_{\mathrm{s}}, \mathrm{T}_{\mathrm{p}}, \mathrm{T}_{\mathrm{m}}$ & 0.5 & $1992-2001$ \\
\hline Cesenatico buoy & $44^{\circ} 12.9^{\prime}$ & $12^{\circ} 28.5^{\prime}$ & 10 & $\mathrm{H}_{\mathrm{s}}, \mathrm{Dir}, \mathrm{T}_{\mathrm{p}}, \mathrm{T}_{\mathrm{m}}$ & 0.5 & 2007-today \\
\hline Ancona buoy & $43^{\circ} 49.8^{\prime}$ & $13^{\circ} 42.8^{\prime}$ & 75 & $\mathrm{H}_{\mathrm{s}}$, Dir, $\mathrm{T}_{\mathrm{p}}, \mathrm{T}_{\mathrm{m}}$ & 0.5 & 1999-2006 \\
\hline SWAN virtual buoy & $44^{\circ} 19.9^{\prime}$ & $12^{\circ} 24.0^{\prime}$ & 10 & $\mathrm{H}_{\mathrm{s}}, \mathrm{Dir}, \mathrm{T}_{\mathrm{p}}, \mathrm{T}_{\mathrm{m}}$ & 1 & $2005-2008$ \\
\hline
\end{tabular}


second has been specifically developed to analyse the National Wave Buoy Network dataset (Corsini et al., 2004). This method identifies a storm if the wave height persists over the threshold of $1.0 \mathrm{~m}$ for more than 12 consecutive hours. If the height decays below the threshold of $1.0 \mathrm{~m}$ for less than 6 consecutive hours the two events are considered separate. The wave direction is also controlled and has to come from a well-defined sector $\left( \pm 30^{\circ}\right.$ with respect to the wave direction at the beginning of the storm).

Another methodology specific to the Western Mediterranean by Mendoza and Jimenez (2004) was adapted to the Northern Adriatic by Armaroli et al. (2007a). Unlike the two previous ones, it also takes into account the storm duration. Based on the original work of Dolan and Davis (1992), it introduces an energy classification of the storms. The energy content of each storm is defined as the time integral of the squared significant wave height computed between the beginning and the end of the event. The wave threshold however also needs to be defined. In this study a storm is defined as an event with significant wave height higher than $1.5 \mathrm{~m}$ and remains over the threshold for at least $6 \mathrm{~h}$. Two storms are considered separate if the wave height decays below the threshold for 3 or more consecutive hours. The wave direction is not taken into account because of the lack of direction information in some of the datasets available for this study. Each storm is then characterised based on the energy classes of Mendoza and Jimenez (2004).

The hydrodynamic information, meaning water levels and wave characteristics, which were associated with each observed event, were: (i) max water elevations occurring during the storm or $12 \mathrm{~h}$ before and after the peak of the storm. Tide data were collected between 1997 and 2008 by the tide gauge of the Rete Mareografica Nazionale located in Ravenna (Fig. 2A), with a sampling interval of $10 \mathrm{~min}$. An analysis was performed to identify extreme water levels that were $>=+0.45 \mathrm{~m}$ above MSL, which can be considered as a "normal" Spring High Tide. Although the tidal data have been recorded regularly since 1997 , it was decided to use only the data from 2000 onwards as previously some datum shifts of the sensor appeared from the examination of the time-series; (ii) according to data availability, wave characteristics were obtained from PCW (Eni Oil Rig) non-directional wave gauge, Ancona RON directional wave buoy, AA_CNR Venice non directional wave gauge and ARPA Cesenatico directional wave buoy (Fig. 2A).

Although some authors have recently discussed the fact that there may be a complex relationship between extreme wave return period and extreme erosion (Callaghan et al., 2009), the undertaking of probabilistic analyses is deemed necessary when dealing with the impact of extreme storms. A parameterisation of probabilistic events with given return periods was obtained from the literature using the statistical analysis of Yu et al. (1998), who calculated surge levels for events with return periods of 1,10 and 100 years. The work of these authors is considered reliable as it used a wind circulation and barometric model for the whole northern Adriatic. Moreover, recent analyses by Masina and Ciavola (2011) based on the time series of the Ravenna tide gauge for the period 2000-2009 confirmed the validity of these return periods for water levels. Significant wave height

\section{Table 2}

The three scenarios of significant wave height $\left(\mathrm{H}_{\mathrm{s}}\right)$ and period $\left(\mathrm{T}_{\mathrm{s}}\right)$ for each return period $(1,10,100$ years $)$ and surge levels associated.

\begin{tabular}{|c|c|c|c|c|c|c|}
\hline \multirow[t]{2}{*}{ Direction (north) } & \multicolumn{2}{|l|}{ T1 } & \multicolumn{2}{|l|}{ T10 } & \multicolumn{2}{|l|}{ T100 } \\
\hline & $\mathrm{H}_{\mathrm{s}}(\mathrm{m})$ & $\mathrm{T}_{\mathrm{s}}(\mathrm{s})$ & $\mathrm{H}_{\mathrm{s}}(\mathrm{m})$ & $\mathrm{T}_{\mathrm{s}}(\mathrm{s})$ & $\mathrm{H}_{\mathrm{s}}(\mathrm{m})$ & $\mathrm{T}_{\mathrm{s}}(\mathrm{s})$ \\
\hline $30^{\circ}$ & 3.3 & 7.2 & 4.7 & 8.2 & 5.8 & 9.0 \\
\hline $60^{\circ}$ & 3.6 & 7.4 & 4.9 & 8.3 & 6.2 & 9.2 \\
\hline $90^{\circ}$ & 3.5 & 8.4 & 4.9 & 9.6 & 6.2 & 10.7 \\
\hline $120^{\circ}$ & 2.8 & 7.8 & 4.2 & 9.4 & 5.5 & 10.8 \\
\hline Mean values & 3.3 & 7.7 & 4.7 & 8.9 & 5.9 & 9.9 \\
\hline Surge (m) & 0.85 & & 1.039 & & 1.28 & \\
\hline
\end{tabular}

$\left(H_{s}\right)$ and significant wave period $\left(T_{s}\right)$ were taken from IDROSER (1996) that statistically computed them using empirical relationships that were calibrated with long-term wave data recorded by gauges mounted on oil platforms in front of Lido di Dante. The characteristics of the events are presented in Table 2.

\subsection{Historical storm database and impact evaluation}

The historical marine storm database was created after a meticulous search of all available information from a multitude of sources. Generally there is more information on areas that are significant for the regional income and that are exploited for tourism. Moreover, urbanised zones are monitored by Civil Protection to protect people and goods from marine storms. There are many unpublished reports on the interventions done by Civil Protection during past and recent storms to minimise damages and population risk. Data on damage to natural zones, although fewer, have been published recently (see for example Ciavola and Armaroli, 2010).

A first step was to gather available data from local offices of regional authorities (Servizi Tecnici di Bacino delle Province Costiere), that have had competence for coastal safety and protection since the 1980s. Information was mainly collected from technical reports of inspections undertaken after significant marine storms and the consequent list of damages to coastal structures. Reports were also available on interventions done to restore affected areas. Regarding storms known historically for their significant impacts across the region, a search was performed using the internet and local/national newspaper archives. This was later extended to more recent events documented by local authorities, after consultation with end-users.

The spatial information on historical storms was analysed using GIS to describe all the different type of impacts that were registered in the technical reports and by the Civil Protection. From this analysis it was decided to create maps of impact categories to visualise where, how and with which frequency the coastline was affected by marine storms. Fortunately, major storm consequences for the last 20 years were monitored using remote sensing techniques (e.g.: aerial photographs, satellites, Lidar, Argus video system) so it was possible to have a detailed regional overview of the damage caused by the most extreme events.

For every storm that historically caused real damage on the coast a form was compiled including all the available and collected information. In each form, if available, an analysis of waves and tidal levels during the storm was also added, synoptic maps and pictures of damaged and/or flooded areas and for the Lido di Dante site only, Argus video information.

\subsection{Topographical surveys on the ground and Lidar data}

Information used to evaluate the morphology of the beach in natural and urbanised zones and the location of coastal structures were extracted from two Lidar flights: one (DSM, digital surface model) performed in July 2003 by the ENI (Ente Nazionale Idrocarburi) oil company; and another (DSM and DTM, digital terrain model) done in September 2004 by the Regione Emilia-Romagna. Both flights covered almost the entire coastline. The second Lidar survey performed on 24-27 September 2004 is particularly valuable as it took place immediately after a 25-yr storm return period (Ciavola et al., 2007b). In order to provide a pre-/post-storm assessment, morphologies were compared along 41 profiles spaced $250-500 \mathrm{~m}$ inside the Ferrara and Ravenna Provinces, (Fig. 6). The location of each cross-section was defined by a series of cross-shore profiles that have been regularly monitored by the regional authorities since 1994 along the whole coastline every $500 \mathrm{~m}$ (topo-bathymetric surveys done in 1994, 1998, and 2006). In the MICORE study area (Lido di Dante and Lido di Classe) it was decided to increase the number of sections by adding extra profiles, thereby enhancing the spacing to $250 \mathrm{~m}$. 


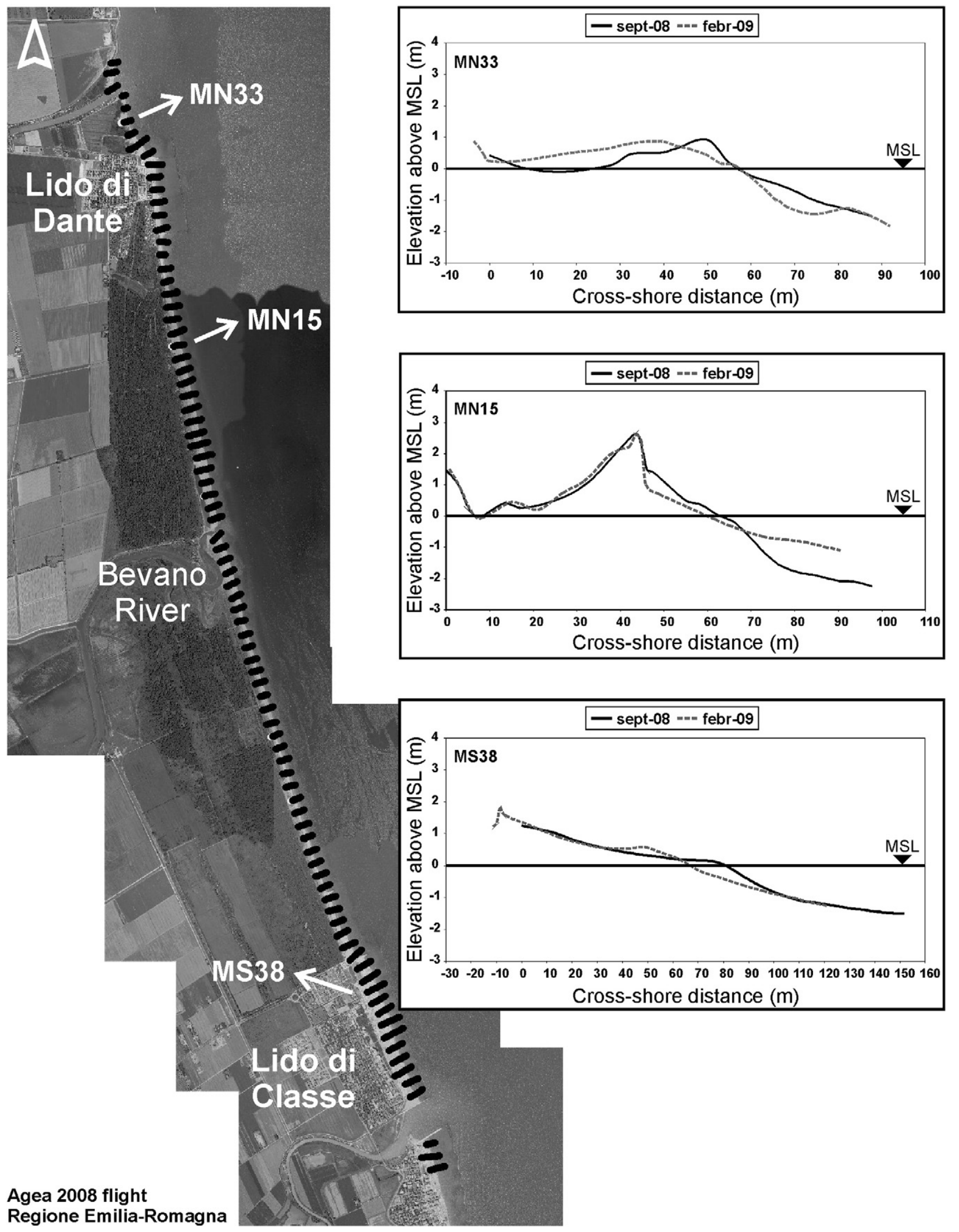

Fig. 5. Location of the profiles surveyed along the Lido di Dante-Lido di Classe coastline for the MICORE Project and examples representative of the main beach and dune morphologies observed during the monitoring programme: MN33, natural area that suffers from overwash; MN15, natural area with dunes that suffers from frontal dune erosion; MS38, urbanised beach protected by longshore breakwaters that suffers from flooding. To note the presence of an artificial sand embankment at the landward edge of the MS38 profile in February 2009. 
Another comparison was done, only for the study area, between two topographic surveys performed in September 2008 and in February 2009. The two datasets were specifically collected for the MICORE Project (Fig. 5). All the topographic surveys were performed using RTKDGPS. The measurements were done along equally spaced profiles $(100 \mathrm{~m})$ along the $8 \mathrm{~km}$ of coastline. As the tidal range is small and at low water the inner bar is often submerged, cross-shore profiles were extended onto the submerged beach by wading with fishermen boots or wetsuits. Profiles were also extended to the rear of the dunes to evaluate the cross-sectional area of the dunes and to assess the storm impacts in areas of overwash generation.

3.5. Critical storm thresholds for the generation of morphological changes: statistical scenarios-natural areas

According to previous studies (Armaroli et al., 2007b; Ciavola et al., 2007a,b; Ciavola and Armaroli, 2010), the dune system in the case study area of Lido di Dante is often affected by storms showing frontal dune erosion, overwash, overtopping and blow outs. The types of dune erosion can be grouped using the classification of Short and Hesp (1982). On the basis of the categories of dune variability, a threshold for morphological change was defined according to the dune cross-sectional area calculated between the dune foot and dune crest (Fig. 6). The "original" dune volume was then compared to the cross-sectional area calculated between the elevation reached by the maximum water during storms and the dune crest. In fact it was clearly demonstrated in previous work that the dunes are more vulnerable if they have a limited "sand reservoir" (Vellinga, 1982, 1986). This reservoir was defined as the amount of sand that composed the dune from its foot up to the crest down to the rear dune. A very high dune, but with a narrow cross-section, is therefore more vulnerable to erosion and destruction than a lower one which has a wider cross-section and larger amount of sand.

We decided to use a simple indicator, the Dune Stability Factor (DSF, Fig. 6; Armaroli et al., 2007b), that can describe dune vulnerability having as input information data derived from previous studies, meaning not time series of hydrodynamic conditions but static information, like beach and dune surveys.

The DSF is defined as:

$\mathrm{DSF}_{\%}=\frac{\text { A_hmax }}{\text { A_dunefoot }} * 100$

where A_hmax is the cross-sectional area calculated between the max level reached by the marine water during storms $(\mathrm{MWL}=$ runup + set-up + tide + surge) and the dune crest (defined for different dune configurations, from the classification of Short and Hesp (1982). As pictorially described in Fig. 6, A_dunefoot is the crosssectional area between the dune foot and the dune crest.

The "maximum" water level, MWL, derives from a combination of three "worst-case scenarios" - storms occurring in conjunction with an atmospheric surge (Table 2) and a high spring tide. Wave characteristics and surge levels that were used for the analysis are the 1-in-
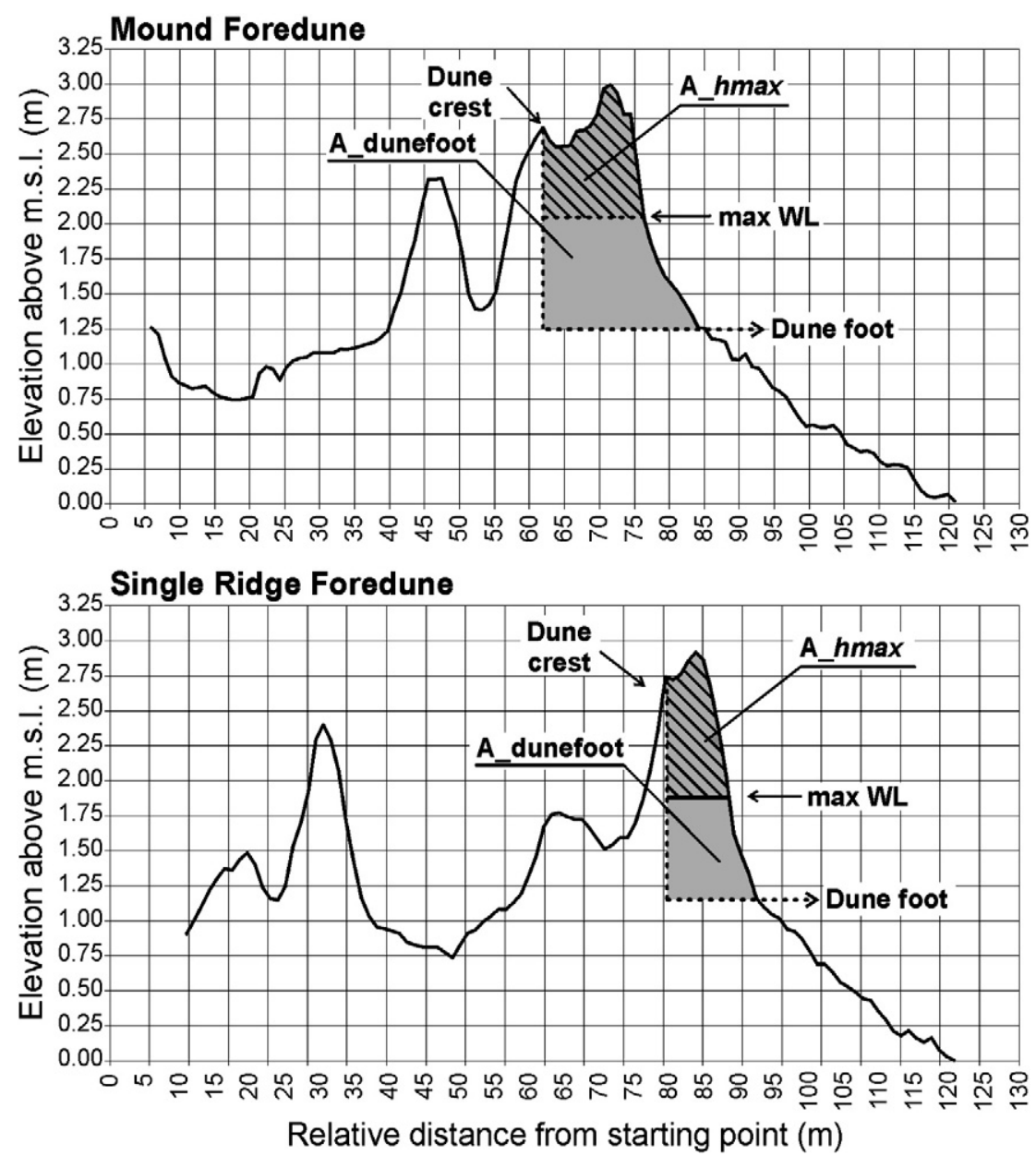

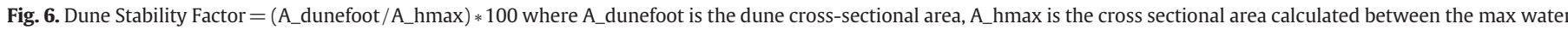
elevation (for each scenario, see below for the definition of "scenario") and the dune crest. 
1, 1-in-10, 1-in-100 years return period values of Table 2. Wave parameters were used to compute the run-up along each beach profile using the Holman (1986) formula modified by Komar (1998) to include the set-up (Eq. (2)):

$\mathrm{R}_{2 \%}^{\mathrm{T}}=0.36 \mathrm{~g}^{1 / 2} \mathrm{SH}_{\infty}^{1 / 2} \mathrm{~T}$

where $R_{2 \%}$ is the $2 \%$ exceedance run up level, $g$ is the acceleration of gravity, $\mathrm{S}$ is the beach slope, $\mathrm{H}_{\infty}$ is the deep water wave height and $\mathrm{T}$ is the deep water wave period.

To estimate the morphological damage generated by the water elevation along each cross-section the DSF is thus used as an index of vulnerability. If the DSF is below $20 \%$ the dune is considered vulnerable to complete removal and erosion, implying that it would probably be obliterated and water would overwash and inundate the area behind it. If the percentage is between $20 \%$ and $75 \%$ the dune is considered vulnerable to frontal erosion, meaning that it is eroded but can withstand prolonged storm action. Finally, if the DSF is above $75 \%$ the dune is not believed to be vulnerable. Then each DSF value was associated to a definition of the corresponding effect: above or equal to $75 \%=$ profile intersection (safe condition); between $20 \%$ and $75 \%=$ front dune erosion; below or equal to $20 \%=$ dune obliteration.

To define the DSF percentage values listed above, a comparison was made between the 2003 Lidar data with the 2004 Lidar. Another comparison was made using the MICORE baseline survey performed in September 2008 and a second one done in February 2009 for the case study site. The analysis was performed along several transects inside the case study site (Lido di Dante-Classe, for both cases) and inside natural areas in the northern part of the Emilia-Romagna Region (Ferrara province, for the 2004 event only). There are some exceptions that do not show a correspondence with the DSF percentages defined for the three scenarios but in general there is a good agreement between the DSFpredicted vulnerability and the observed erosion (almost $70 \%$ of the analysed profiles using Lidar data and almost 90\% using MICORE surveys).

\subsection{Critical storm thresholds for damages to infrastructures/human} occupation: highly urbanised zones

The methodology used to find critical conditions for inundation/ damage considers the same hydrodynamic information already used for the definition of the DSF and was applied to the whole regional coastline that is protected by structures and highly urbanised (along cross-sectional transects extracted from Lidar 2004, spaced $500 \mathrm{~m}$ ). The water level increase during energetic conditions $(\mathrm{MWL}=$ runup + set-up + surge + tide, described above for natural areas) was then compared to the maximum topographic elevation along each profile and to the location of buildings and structures on or next to the beach. This methodology is similar to the one proposed by Ruggiero et al. (2001). The authors compare the elevation of the beach-face junction $\left(E_{J}\right)$ with the total elevation of water during storms including the maximum run-up. In that case, $\mathrm{E}_{\mathrm{J}}$ is the limit between the cliff and the beach or the dune foot. In our case, as we are in urbanised zones, the limit used for the comparison was chosen along each profile as the position of human structures identified on the DSM (Digital Surface Model, from the Lidar 2004). In our case the beachface junction of Ruggiero et al. (2001) is the position and elevation of the seaward limit of properties located on the beach or immediately behind. This "junction" was then compared to the MWL to evaluate the vulnerability of human properties to damage/inundation. To identify the effect of the three probabilistic scenarios on urbanised areas three damage categories were created in order to display the results on a GIS.

The effect of different water levels had to be considered in relation to the topographic elevation of anthropogenic areas. For this reason two important profile characteristics were analysed along 63 transects that crossed built-up zones (extracted from Lidar 2004, Fig. 3): (i) the maximum profile elevation (defined as the maximum height above MSL along each profile); (ii) to know the contribution to inundation by run-up only, the slope of each profile (from MSL to the seaward limit of human structures) was used to compute the run-up elevation.

In this case, run-up was estimated using two formulae: Holman's (1986) modified by Komar (1998) and Stockdon et al. (2006). The formula by Komar (1998) was already described above. The general formula of Stockdon et al. (2006) is:

$\mathrm{R}_{2 \%}=1.1\left(0.35 \beta_{f}\left(H_{0} L_{0}\right)^{1 / 2}+\frac{\left[H_{0} L_{0}\left(0.563 \beta_{f}^{2}+0.004\right)\right]^{1 / 2}}{2}\right)$

where $\beta_{f}$ is the beach slope, $H_{0}$ is the deep water wave height and $L_{0}$ is the deep water wave length. Eq. (3) is suitable for all the different kinds of beaches, from dissipative, intermediate to reflective. The associated RMSE (Root Mean Square Error) is $38 \mathrm{~cm}$. The authors compared the run-up calculated using the formula on dissipative beaches $\left(\xi_{0}<0.3\right)$ with the run-up computed on intermediate and reflective beaches, reaching the conclusion that for dissipative slopes the beach slope should be excluded from the formulation. This improved the relationship between the run-up and $H_{0} L_{0}$, reducing the RMSE to $21 \mathrm{~cm}$.

The formula for dissipative beaches is then:

$\mathrm{R}_{2 \%}=0.043\left(H_{0} L_{0}\right)^{1 / 2}$

For this paper it was preferred to use the last formula because an unpublished study done by the authors revealed that most of the Emilia-Romagna coastline is composed of dissipative beaches.

The number of profiles that were used to compare results derived from the max water level calculation (using both formulae, Holman, 1986; Stockdon et al., 2006) with the max topographic elevation to determine the robustness of the chosen thresholds (see below) are 63 (highly urbanised areas in Fig. 3).

All run-up formulae require the deepwater wave conditions as an input. While the probabilistic wave parameters of Table 2 are referred to deep water and can be considered valid for open beaches, in the case of beaches behind breakwaters one should account for the sheltering effect provided by the structure. The offshore wave conditions were propagated up to the breakwaters edge using linear wave theory and wave transmission over the structure was accounted for, using the methodology developed by Armaroli et al. (2009).

\section{Results}

\subsection{The historical storm database}

To try to identify the mean forcing conditions that are hazardous for this coast, all available data on damage (mainly inundation and erosion) to anthropogenic areas were collected between 1966 and 2008. This information is very important because it identifies observed "damaging" events that can be characterised (using waves and water level that occurred during the storm) with their associated impact on human structures. The most extreme storm recorded in the area, with observed damage along the whole Northern Adriatic coast, took place on 4 November 1966 . Wave hindcasts of this storm by De Zolt et al. (2006) for the Venice area suggested that wave heights reached $6 \mathrm{~m}$ in conjunction with a surge level with a return period of 250 years (Lionello, 2005). According to Canestrelli et al. (2001) the high tide in Venice reached $1.94 \mathrm{~m}$, the largest level ever recorded by the Venice tide station.

Regarding quantitative information on waves and water levels for the Ravenna area, although some measurements of one of the parameters may be available for periods beforehand, simultaneous measurements only occur from 1992 onwards (Table 3). Pre-1992 
Table 3

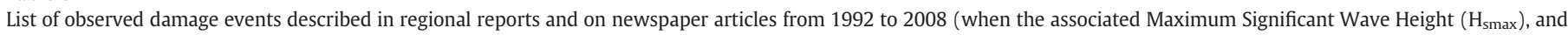

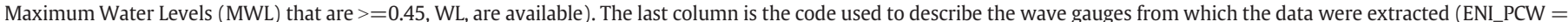

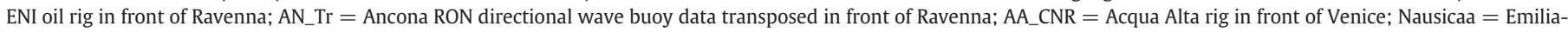

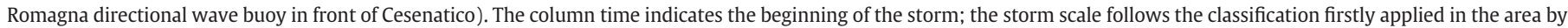
Armaroli et al. (2007a). The ENI_PCW and AA_CNR datasets are non-directional measurements, the direction is inferred from wind measurements taken at the site.

\begin{tabular}{|c|c|c|c|c|c|c|c|c|c|c|}
\hline Day & Month & Year & Time & $\begin{array}{l}\text { Duration } \\
\text { [hours] }\end{array}$ & Class & $\begin{array}{l}\mathrm{H}_{\mathrm{smax}} \\
{[\mathrm{m}]}\end{array}$ & $\begin{array}{l}\mathrm{Tp} \\
\mathrm{H}_{\text {smax }}[\mathrm{sec}]\end{array}$ & $\begin{array}{l}\text { Dir } \\
\mathrm{H}_{\text {smax }}\left[{ }^{\circ} \mathrm{N}\right]\end{array}$ & $\begin{array}{l}\text { Max } \\
\text { WL [m] }\end{array}$ & Wave gauges \\
\hline 8 & 12 & 1992 & $06: 30$ & 37.5 & 3 & 3.94 & No data & 55 & No data & ENI_PCW \\
\hline 28 & 12 & 1992 & $00: 30$ & 28.3 & 3 & 4.00 & No data & 27 & No data & ENI_PCW \\
\hline 25 & 12 & 1996 & $19: 00$ & 52.0 & 4 & 4.24 & No data & 38 & No data & ENI_PCW \\
\hline 6 & 11 & 1999 & $19: 30$ & 75.5 & 3 & 3.48 & No data & 136 & No data & AN_Tr \\
\hline 14 & 11 & 2002 & $17: 00$ & 63.5 & 3 & 4.70 & 9.51 & 30 & 0.96 & AN_Tr \\
\hline 18 & 11 & 2002 & 01:00 & 25.0 & 2 & 2.98 & 8.47 & 15 & 0.85 & AN_Tr \\
\hline 24 & 11 & 2002 & $12: 30$ & 73.0 & 4 & 3.58 & 8.60 & 24 & 0.7 & AN_Tr \\
\hline 3 & 12 & 2002 & $20: 30$ & 48.0 & 3 & 3.33 & 7.14 & 72 & 0.91 & AN_Tr \\
\hline 7 & 12 & 2003 & $00: 30$ & 56.5 & 3 & 3.33 & 7.73 & 41 & 0.56 & AN_Tr \\
\hline 3 & 5 & 2004 & $23: 00$ & 23.0 & 2 & 2.59 & 7.23 & 110 & 0.65 & AN_Tr \\
\hline 24 & 9 & 2004 & $16: 30$ & 68.0 & 3 & 5.65 & 9.32 & 17 & 0.85 & AN_Tr \\
\hline 31 & 10 & 2004 & 03:00 & 21.5 & 2 & 2.35 & 7.89 & 104 & 0.82 & AN_Tr \\
\hline 9 & 11 & 2004 & $22: 00$ & 23.0 & 2 & 2.39 & 6.38 & 133 & 0.92 & AN_Tr \\
\hline 14 & 11 & 2004 & $00: 00$ & 27.0 & 2 & 2.12 & No data & No data & 0.88 & AA_CNR \\
\hline 26 & 12 & 2004 & $02: 30$ & 41.5 & 3 & 3.43 & 8.49 & 114 & 0.94 & AN_Tr \\
\hline 10 & 4 & 2005 & $18: 00$ & 30.0 & 2 & 2.50 & No data & No data & 0.8 & AA_CNR \\
\hline 3 & 10 & 2005 & $12: 30$ & 7.0 & 1 & 1.88 & 6.55 & 105 & 0.57 & AN_Tr \\
\hline 8 & 10 & 2005 & 03:00 & 6.5 & 1 & 2.12 & 6.61 & 99 & 0.63 & AN_Tr \\
\hline 22 & 11 & 2005 & 03:00 & 18.5 & 2 & 2.79 & 7.74 & 35 & 0.47 & AN_Tr \\
\hline 3 & 12 & 2005 & 03:00 & 12.0 & 1 & 2.20 & No data & No data & 0.8 & AA_CNR \\
\hline 30 & 7 & 2007 & $17: 30$ & 16.0 & 2 & 2.98 & 8.33 & 57.7 & 0.58 & Nausicaa \\
\hline 4 & 9 & 2007 & $07: 30$ & 8.0 & 1 & 2.78 & 6.67 & 21.1 & Below threshold & Nausicaa \\
\hline 10 & 12 & 2008 & $16: 00$ & 14 & 1 & 1.99 & 10 & 81.6 & 0.8 & Nausicaa \\
\hline 11 & 12 & 2008 & $17: 30$ & 16 & 1 & 1.95 & 11.11 & 87.2 & 0.87 & Nausicaa \\
\hline 12 & 12 & 2008 & $14: 30$ & 13.5 & 1 & 2.17 & 7.14 & 67.5 & 0.87 & Nausicaa \\
\hline 25 & 12 & 2008 & $20: 30$ & 27 & 3 & 3.18 & 8.33 & 60.5 & 0.55 & Nausicaa \\
\hline 27 & 12 & 2008 & $12: 00$ & 20.5 & 2 & 2.00 & 6.67 & 47.8 & Below threshold & Nausicaa \\
\hline
\end{tabular}

records therefore can only be used as a qualitative understanding of what happened in the past. The only data included in these reports are a general description of the damage to structures and infrastructure. Regarding the event, it is only reported when it occurred without any analysis of the percentage of anthropogenic elements that were affected and without any topographic survey to quantify beach erosion and the amount of coastline that was inundated.

Between 1992 and 2008 there were two significant storms. One occurred in December 1992 and the other in September 2004. Aerial photographs of the whole coastline were taken after the 1992 storm, so it was possible to extract from the photos detailed information on flooded areas, damaged structures, beach erosion, etc. After the 2004 storm a Lidar Flight was done, so there is information on the volumetric change and sediment loss occurred on the beach and dunes. For both storms it was possible to compare the previous year coastal configuration (aerial photos taken in 1991 and Lidar Flight done in 2003 both in "calm" periods) with the post-storm data to evaluate the real effect of the events.

Since 1966, 27 extreme marine events occurred on the coast of the Emilia-Romagna Region and were able to generate widespread damage along the coastline, e.g. inundation of the backshore, strong beach erosion, destruction of or damage to properties located on the beach or behind it. We cannot exclude that events other than those catalogued occurred, but they were not registered in newspapers so that they are not present in the historical storm database. The majority of the collected storms (21 out of 27) are associated with high surge levels. These events are typical of the winter period between November and December.

All the collected information was then visualised on maps of different damage types generated by historical storms along the whole coastline. The most significant damage types were chosen considering the main type of impact for each costal area: river flood, sea flood, beach erosion (Fig. 7). The frequency (number of occurrences) of each damage class is identified in the maps using circles with radii proportional to the occurrence (Fig. 7). River flood and dike overtopping happen when an atmospheric storm occurs at the same time as a marine one. Heavy rainfalls together with high waves, that obstruct the river discharge, generate floods that inundate the area behind the beach and villages. Sea floods are generated by high surge levels combined with wave set-up and run-up. Beach erosion is produced by a combination of several factors including the above cited categories. It was decided to represent the impacts as reported in consulted newspapers, web pages, etc., to create the historical storm database. Here the effect of a storm is often described quite reliably in terms of beach erosion, river and sea floods and/or the combination of these three events. Among the produced damages, the most significant ones are beach and dune erosion and coastal floods, which are sometimes associated with heavy rainfall and the consequent overflow of rivers in coastal areas. On the basis of these two different types of impacts, the coastline was classified and divided into two main parts. The southernmost has a higher elevation above MSL compared to the northern one and generally suffers more from erosion. The northern one in comparison is generally damaged more by flooding rather than by other processes.

The total number of the catalogued impacts is 218. The Bora (ENE) events are 141 while the remaining ones are from SE. The most damaged places, as indicated in Fig. 7, are located in the northern area of the Region (Lido di Volano, Lido delle Nazioni and Lido di Spina southern part, Ferrara Province). Other places that were affected by historical storms are located in the central and southern parts of the coast such as Punta Marina, Lido Adriano and Lido di Savio (Ravenna Province), Cesenatico and, along the Rimini Province, Misano Adriatico (Fig. 7). Note that the area of Lido di Volano was frequently damaged by winds from SE (as they generate high surge levels compared to the elevation of the coastline that is low with respect to the MSL). This area was particularly hit by the 1966 storm, with inundation occurring up to $2 \mathrm{~km}$ inland from the beach. After this disastrous event several dykes (the Acciaioli Line) were built inland in order to protect the 

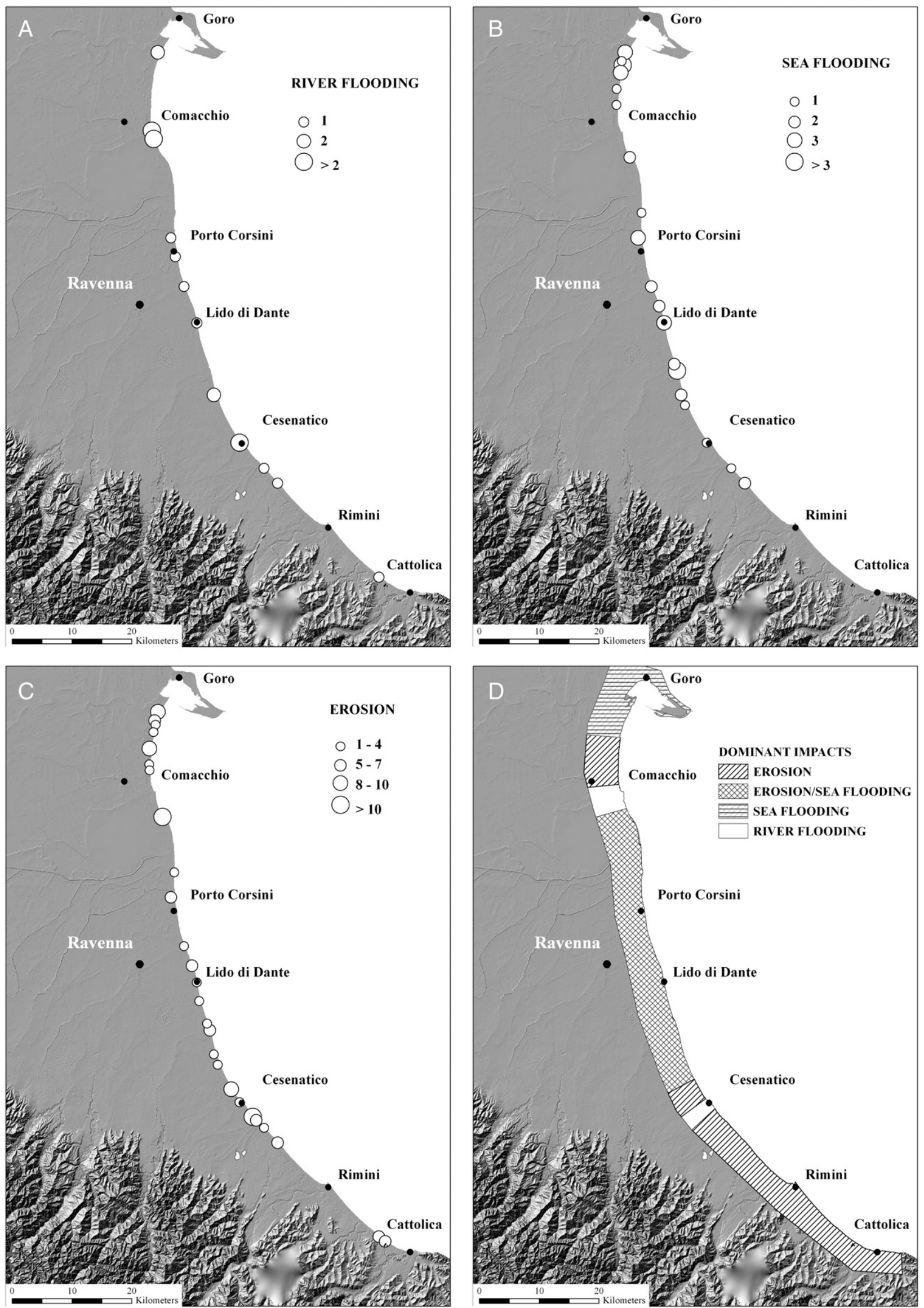

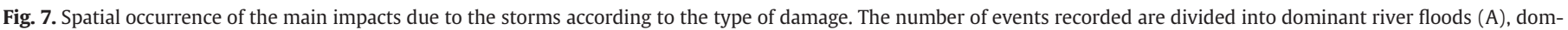
inant sea floods (B), beach erosion (C); (D) is a classification of the coastal segments according to the dominant process. 

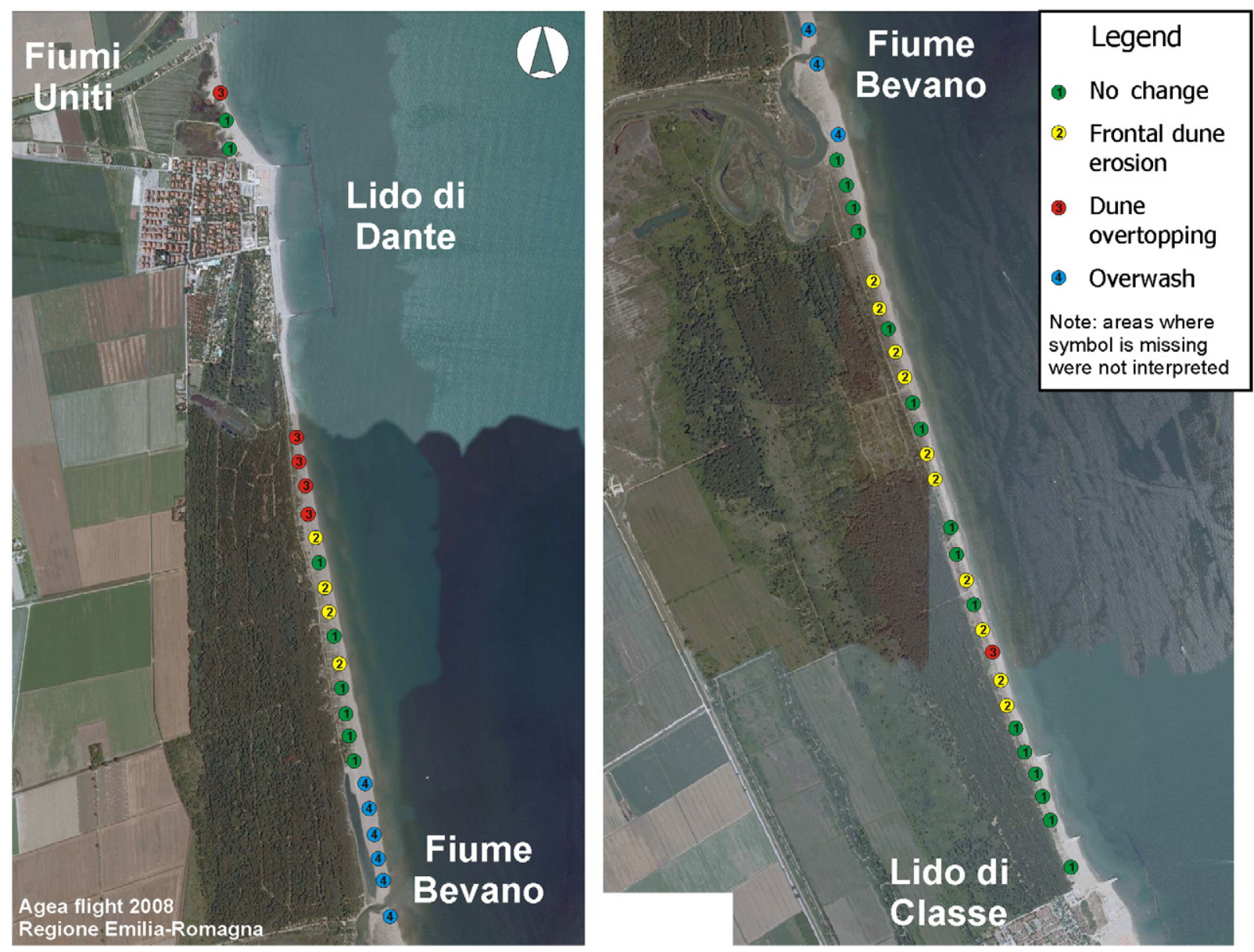

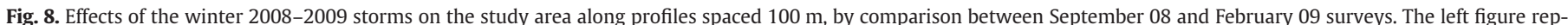
resents the area between the Fiumi Uniti River and the Bevano River; the right figure represents the area between the Bevano River and the Lido di Savio village.

territory from marine floods. The area is still very vulnerable as these dykes do not protect the majority of the coast but only a small part of it. Indeed after the construction of the dykes, much coastal development took place, with the construction of new buildings seaward of the defences. Thus there are tourist villages that are exposed to extreme events and not protected by banks.

\subsection{Morphological impact}

Comparisons between the two topographic surveys of the case study site done in September 2008 and in February 2009 for the MICORE Project revealed that the 2008-2009 winter was not energetic enough to generate significant dune and beach erosion. It is noticeable that in December 2008 a cluster of small to medium energy storm events (with max storm $\mathrm{H}_{\mathrm{s}}$ between 1.99 and $3.18 \mathrm{~m}$ ) occurred, causing severe damage along the whole regional coastline, but less significant impacts on the natural part of the study site. The event mentioned above can be considered representative of wave conditions that approach the 1-year return period. The data analysis revealed that at several locations retreat of the dune foot occurred and some foredunes were eroded (Fig. 8). The reconstructed dunes to the north of the Bevano mouth were also overwashed. One profile located between the Lido di Dante village and the F. Uniti mouth, that historically suffered from inundation and that every winter is overwashed by waves, suffered severe erosion of the shoreface, and back-barrier migration. In the analyses presented in Fig. 8, a distinction was made between the "dune overtopping" impact and the overwash s.s. In the dune overtopping category, in the field it was observed that the maximum water level during the storm had only caused limited inland sediment transport, the frontal dune ridge was eroded only on the seaward side and was still standing after the storm. In this sense our overtopping category represents the boundary between the collision and overwash regimes of Sallenger (2000).

The analysis showed that there are some profiles that suffered from overwash and others where the dunes were damaged by frontal erosion. From previous work done on dune vulnerability in the area (Ciavola et al., 2007a), the locations along the study site that are in critical positions are those where the dunes are always affected by marine storms, even for medium energy events.

The area located to the north of the Bevano mouth is occupied by dunes that were reconstructed in April 2006 (Gardelli et al., 2007) with a low crest elevation above MSL $(1.5 \mathrm{~m}$ ) and that are frequently overwashed (Fig. 8, category 4). Here the beach is very dissipative and the run-up is not the main process that causes overwash events. Instead the main forcing agent is the surge level, even under conditions of low wave energy. The classification of the dune evolution presented in Fig. 8 was obtained through the comparison between the baseline survey done in September 2008 and the February 2009 survey.

During the morphological monitoring in the winter 2008/2009, three types of profile change were observed (Fig. 5-MS38). (A) overwash of low-lying dune ridges, with translation inland of the sediment volume lost from the intertidal zone; (B) frontal dune erosion, with dune toe undercutting but not overtopping; (C) inland migration of the berm in profiles protected by offshore breakwaters. Case (A) corresponds to the overwash regime (Impact Level 3) of Sallenger (2000), while case (B) is equivalent to the collision regime (Impact Level 2) of the same classification. Case (C) could be compared 
to the swash regime of Sallenger (2000) but with some differences. The classification of these authors predict that during storms the sand eroded from the foreshore would move offshore and return to the emerged beach during fair weather conditions. In the case of profiles located at Lido di Classe (Fig. 5), after the storms of the winter 2008/2009 the net change of the lower intertidal zone is limited and there is no evidence of deposition on the submerged beach. On the other hand, a high berm is built up. This could be due to two processes: first, the presence of the breakwater that controls the breaking of storm waves outside the structure, so that only small waves break on the beachface with dominant run-up processes responsible for berm accretion. Second, as the surveys were done at spring tides in a period of very calm seas, the build-up of the berm was controlled by tidal action. This is a process which is common on these beaches behind breakwaters, as experimentally observed during intensive field measurements in 2008 by Sedrati et al. $(2008,2009)$.

\section{Discussion of critical storm thresholds}

\subsection{Natural areas}

Critical storm thresholds for morphological changes were defined for natural areas. The definition of "morphology" can have different meanings. The morphological response is related to the behaviour of the beach as a geomorphological element that can be described through different morphodynamic states: presence/absence of intertidal morphologies, submerged bars, berms and dunes. If one wants to take into account the behaviour of a beach as a natural element able to change according to marine and meteorological forcing factors (showing different winter and summer configurations) it is not possible to include most of the coastal zones of the Italian MICORE regional coastline into this definition. Indeed, as previously mentioned, here the disturbance due to local users carrying out profile reshaping before and after the winter creates beach slopes that are not natural. As this happens in areas with coastal structures, for the definition of "natural morphological thresholds" only beaches with dunes and low level of occupation were considered.

In natural areas characterised by the presence of dunes and absence of human occupation the definition of morphological impact was done according to DSF values. It was decided to consider as a "morphological impact event" a storm able to affect at least $2 / 3$ of the total number of analysed profiles (41, Fig. 4). In Table 4a list of the percentages of the effects on the dune system for each scenario are listed. The effects are defined according to DSF values as described in Section 3.5. It is clear that the T1 event damages $61 \%$ of the dune system. It is important to note that there are some parts of the dune ridge that are able to resist the attack of high waves and high surge levels. In fact according to Table 4 there are two sections (5\%) where the T100 scenario causes "profile intersection", meaning, as we have already outlined before, a "safe" condition.

The decision to evaluate coastal vulnerability using probabilistic scenarios, and not pre- and post- storm information together with time series of wave records, derives from the need for coastal managers to use simple and accessible data (wave height and surge levels analysed in previous studies) to know if a zone is vulnerable to slight events or to extreme storms, in order to optimise the economic effort.

As pointed out by Judge et al. (2003) the dune crest elevation is not suitable to evaluate the vulnerability of a dune system because

\section{Table 4}

Percentages of the number of studied profiles on the dune system impacted by each storm scenario.

\begin{tabular}{llrr}
\hline Damage category/return period & T1 & T10 & T100 \\
\hline Profile intersection & $39 \%$ & $19 \%$ & $5 \%$ \\
Front dune erosion & $44 \%$ & $36.6 \%$ & $32 \%$ \\
Dune obliteration & $17 \%$ & $44 \%$ & $63.4 \%$ \\
\hline
\end{tabular}

it can be very high above a reference level, but contain a small amount of sand that can be easily eroded by the prolonged attack of waves. The present authors concluded that the crest elevation "shows limited success in predicting the failure of coastal dunes". The authors present an overview of several methodologies where different computations are done on cross-section profiles to generate simple indicators of dune vulnerability to storms. Hallemeier and Rhodes (1988) and Kriebel et al. (1997) introduced storm duration as an erosive factor. In the present study the vulnerability of the dune system is evaluated using probabilistic scenarios, therefore there it does not account for the duration of an event. The "cross-section centroid" of Judge et al. (2003) can be used to introduce the distance between the dune and the shoreline. These authors state that the dune failure or survival is correlated to the "run-up low" as defined by Sallenger (2000), thus not suitable for the analysis presented in our paper, which uses the "run-up high". Finally, Judge et al. (2003) describe also the "erosion resistance" that incorporates all the previous methodologies and hence cannot be applied to our site. Gares (1990) computes instead the maximum water level return periods, as the combination of surge + run-up, but compares the results with the dune height.

The DSF index developed in the current study is somehow a combination of the methods of Judge et al. (2003) and Gares (1990) as we wanted to account at the same time for sediment availability and impact of run-up as in Sallenger (2000). Because of natural variability of the dune cross-section, the choice of the landward "closure" of the polygon used for calculating the sand reservoir of Fig. 6 had to be subjective. We decided to only evaluate the sand reservoir of the foredune, including as crest not just the highest point but also smaller undulations (e.g. see in Fig. 6). This choice was made as we wanted to evaluate the resilience of this "first line of defence" to the storm impact. Of course it would be interesting to know what happens to more inland dunes if the first line of defence fails during the storm. However, this not only implies the use of a profile evolution model able to simulate time-varying erosion, but also an account of dune characteristics. As mentioned earlier, the inner dune ridges in this region are heavily vegetated, often by plant species with a dense cover and having well developed root systems, which impedes sediment mobility. Finally, at many sites the innermost dune ridge of Fig. 6 has been transformed into a coastal walkway and is artificially kept stable. At some sites in the northern part of the regional coastline (Ferrara province), the dune even has a core of artificial material covered by a geotextile mattress.

The analysis of the morphological impact along natural areas reveals that the joint occurrence of the 1-in-1-year return period for waves plus the 1-in-1-year return period for water levels (surge + tide) leads to dune erosion and overtopping. Then it is possible to define as "morphological event parameters" a wave height of $3.3 \mathrm{~m}$ occurring with an exceptional high tide of $0.85 \mathrm{~m}$ above MSL.

According to the validation described above, the role of High Water Levels in undermining dune stability is crucial. This was previously proposed by authors working in macro-tidal areas as being a factor that controls sediment mobility on the upper beach (Ruz and Meur-Ferec, 2004) and as a signal detectable at decadal time-scales (Pye and Blott, 2008). The goodness of the DSF index developed in the current paper is proven as well as its predictive capability for impact in the case study area (globally 60\%). This is comparable with the validation of the Storm Impact Regime of Sallenger (2000) carried out by Stockdon et al. (2007), who obtained an average success rate of $55.4 \%$ using data from the east coast of the USA.

\subsection{Anthropogenic areas}

The morphological impact of storms as described above for natural zones, was not evaluated on beaches in anthropogenic areas. Beach morphological changes (erosion, accretion, etc.) along urbanised 
and protected coastal stretches assume a secondary role compared to the vulnerability of man-made structures to inundation/damage. The effect of storms on the beach is indeed a major management issue but it is compensated for by frequent replenishments mainly before the summer season, in order to have a wide beach for users and to counteract winter sediment losses. From a management perspective, beach erosion can be considered as an important economic issue. The retreat of the shoreline becomes hazardous if it moves back to a location that is too close to tourist structures placed on the beach or behind it. Then, the highest water levels may be able to inundate the back beach, also creating a risk for inhabitants and structures. This kind of situation is analysed here only in terms of damage and inundation and not in relation to erosion. This choice was made considering three main factors: (i) the effort spent by Regional Authorities on preserving tourist areas, with consistent economic resources spent every year to protect occupied coastal stretches; (ii) information on damage to structures during the winter season is regularly collected by the authorities only for protected areas; (iii) these beaches are almost artificial and there is no information on sediment losses and morphological changes due to storms. Recently the Regional Authorities have started a monitoring programme of the replenished areas, giving priority to those that are commonly affected by storms. Another priority for managers is to better understand how sand moves both longshore and cross-shore to improve the performance of replenishments. The winter dunes that are artificially created by the owners of the beach huts to avoid inundation of and damage to their properties (Fig. 1B) were not taken into account in this study, because only a small part of the facilities located on the beach are protected by winter dunes as these are not continuous along the coastline. A more detailed analysis of the capability of the artificial embankments to protect the "bagni" will be the object of future studies.

A completely different approach was chosen for impact assessment in anthropogenic zones, because of their configuration and the available information on damage generated by storms for these areas, which are "event specific". In this case it was chosen to start from the viewpoint of damage to permanent human-made structures on the beach and in the backshore. We believe that the assessment of impacts should be routinely undertaken by competent authorities such as is done for hurricanes in the USA (Froede, 2006; Chaney, 2007). As we show below, this is a crucial point for the identification of thresholds specific to developed areas for evaluating the expected impacts of a given event.

To find a wave height threshold for hazardous events that cause damage along urbanised areas, one should relate the conditions that cause damage with the types of expected impact. In Fig. 9 a classification is presented to describe each damage category. The criteria are comparisons between the computed MWL for each scenario, and the maximum beach elevation of the upper beach. In particular, the first category, "profile intersection/damage", occurs when the maximum water level is very close to the location of structures on the beach; the second one, "damage to infrastructures", occurs when the maximum water elevation is above the maximum profile elevation and intersects the buildings; the third class, "damage to infrastructures and high probability of overtopping", occurs when the maximum water elevation overtops smaller structures that are located in front of larger buildings (e.g. blocks of flats, shops, hotels, restaurants). The maximum water level that intersects the beach profile is considered as a safe condition and described as "profile intersection". If the analysed profile does not cross a human-made artefact but corresponds to a location where there is a gap between two adjacent buildings (e.g. a pathway to access the bagnos), the damage category is defined as "back beach inundation", because the pathway can act as a corridor for the water that can freely flow and inundate the areas that are behind the beach. The percentage of appearance of each category is listed in Table 5 for each scenario.

\section{PROFILE INTERSECTION/DAMAGE}

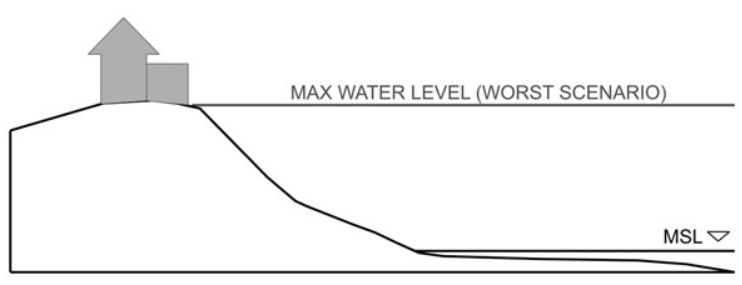

DAMAGE TO INFRASTRUCTURES

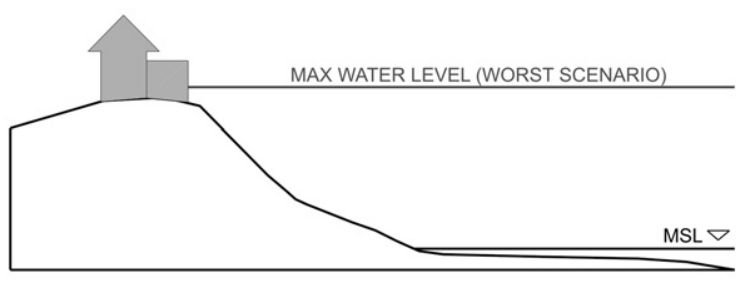

\section{DAMAGE TO INFRASTRUCTURES AND HIGH} PROBABILITY OF OVERTOPPING

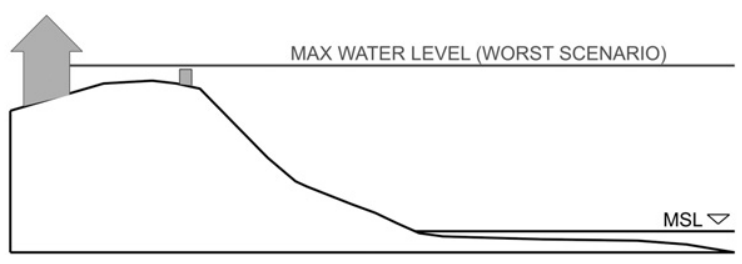

Fig. 9. Damage categories for urbanised areas (explained inside the text).

The percentage of "safe" profiles drastically decreases between the $\mathrm{T} 1$ and the T10/T100 scenarios while there is a consequent increase of damage. The categories "damage to infrastructures" and "back beach inundation" remain almost stable meaning that the analysed profiles are vulnerable also from the $\mathrm{T} 1$ event. This implies that anthropogenic areas are likely to be damaged by marine storms that can occur at least once per year.

The analysis done with data from the literature was compared with information on damages to structures that was collected by the local authorities and/or that was roughly described in newspapers. Although based on qualitative sources, this comparison is important to know if the damage categories created from the scenarios are realistic or not.

To understand the effect of storms along the anthropogenic coastline a plot with Maximum Water Levels (Max WL) versus Maximum Significant Wave Height (Max SWH) was prepared to find the conditions that caused damages. From Fig. 10 it is clear that the wave

Table 5

Percentages of studied profiles in artificial areas impacted by each storm scenario.

\begin{tabular}{lccc}
\hline Damage category/return period & T1 & T10 & T100 \\
\hline Profile intersection & $14 \%$ & $1.6 \%$ & $0 \%$ \\
Profile intersection/damage & $4.7 \%$ & $3 \%$ & $0 \%$ \\
Damage to infrastructures & $64 \%$ & $64 \%$ & $64 \%$ \\
Damage to infrastructures and & $1.6 \%$ & $11 \%$ & $14 \%$ \\
$\quad$ high probability of overtopping & & & \\
Back-beach inundation & $15.6 \%$ & $20.3 \%$ & $22 \%$ \\
\hline
\end{tabular}


height of observed damaging events is always equal or larger than $2 \mathrm{~m}$. The distribution of water levels includes values that are between the elevation of High Water Springs (almost +0.5 above MSL) and almost $+1 \mathrm{~m}$.

The comparison between the analysis using wave and surge parameters derived from the literature (i.e.: probabilistic scenarios) and the information derived from regional reports (i.e.: events that caused real damage) shows that the defined scenarios are more energetic than the real events that affected the coastline. Considering water levels it is possible to conclude that most of the observed events (66.7\%) have a water elevation equal or larger than $0.7 \mathrm{~m}$, that is almost equal to the 1-in-1 year return period surge used for the definition of the T1 scenario $(+0.85 \mathrm{~m})$. Another important consideration is that only 6 out of the 21 maximum $\mathrm{H}_{\mathrm{s}}$ are equal or larger than the 1-in-1 year $\mathrm{H}_{\mathrm{s}}$ derived from the literature. This means that the three scenarios, especially the T1, consider more extreme conditions than those that were able to damage infrastructure and inundate the back beach. The main limitation of this second analysis is that the regional reports and newspapers articles do not clearly define the amount of coastline damaged. Possibly the effect of some of the storms in Fig. 10 did not affect a significant part of the coast but only a limited portion of it. Moreover, newspapers sometimes list damages generated by strong local winds (whirlwinds) that can break beach huts but are unrelated to marine storms. The lack of this information is an important issue as the chosen wave threshold for urbanised zones is quite low compared to the 1 -in- 1 year return period wave. Another analysis done on observed storms is shown in Fig. 11 to account for storm directionality. The distribution of $\mathrm{H}_{\mathrm{s}}$ from E-NE includes a wide range of wave heights mainly equal or larger than $3 \mathrm{~m}$, while storms from SE are located around $2 \mathrm{~m}$. Thus, the chosen threshold includes the storms coming from SE that are those related to highest surge levels but with lower $\mathrm{H}_{s}$ (Fig. 11). The effect of storms is significant even if the associated surge levels only slightly exceed spring high tides, revealing a very sensitive coastline and an increasing effort of the local authorities to mitigate the impact of "not so extreme" events along the coast. The sum between the chosen $\mathrm{WL}+$ run-up + set-up is $1.23 \mathrm{~m}$ with RMSE of $\pm 0.21 \mathrm{~m}$ using Stockdon et al. (2006) for beaches with $\xi_{0}<0.3$, while it becomes 1.04 m using Komar (1998). It must be reminded that the mean maximum elevation of the analysed 63 cross-section is $1.45 \mathrm{~m}$ above MSL. Thus, the maximum water elevation during storms computed using the chosen thresholds is able to inundate and damage between $18 \%$ and $68 \%$ of the total number of analysed profiles.

\section{Conclusions}

This paper proposes a new methodology to identify thresholds for storms that affect the Emilia-Romagna coast. The analysis presented matched a database of observed storm impacts, wave and tide measurements and surveys after storm events. The main outputs were vulnerability classes and thresholds for waves and tides. An innovative aspect of the work is the fact that vulnerability thresholds are not based on pure theoretical evaluations but are validated against observations of damage occurred.

Vulnerability classes and wave and water levels (surge + tide) thresholds were defined for natural areas with dunes. Using probabilistic scenarios for different return periods $(1,10$ and 100 years) a Dune Stability Factor (DSF) was tested and validated to define thresholds for dune erosion/obliteration. Vulnerability classes and thresholds of wave height and water levels (surge + tide) were also defined for urbanised zones based on historical storm information (1992-2008) that describe events able to produce an impact on the coastline, e.g.: flooding, beach erosion, dune overwash, etc.

In Table 6 the chosen thresholds are listed together with the criteria used to define the wave height and water level values that are able to affect the coastline. It is immediately clear that more extreme events have to occur to damage natural zones while the urbanised areas are sensitive even to relatively low energetic sea states.

The storm database that was produced could be followed as an example for a similar exercise in different regions. In the MICORE project effort was spent making this method robust for other areas, but clearly local factors are also critical. In the future the database will be maintained and translated into GIS format for rapid consultation as it can be of benefit for end users in support of strategic coastal planning.

Recently this approach of rediscovering historical archives has proved valuable for flood hazard mapping, to the extent that Bernatchez et al. (2011) propose the creation of a network of observers which should include local communities, to acquire products like in situ observations of storms events (e.g. videos, photographs, etc.). Such a system of acquisition could be managed using online social networks to improve transfer of knowledge to end-users. On the other hand, there is a role for the competent institutions in maintaining and validating the uploaded records.

For the large scale approach at regional level it was decided to characterise dune vulnerability using the DSF index, based on an empirical estimation of Maximum Water Level during the storms. This

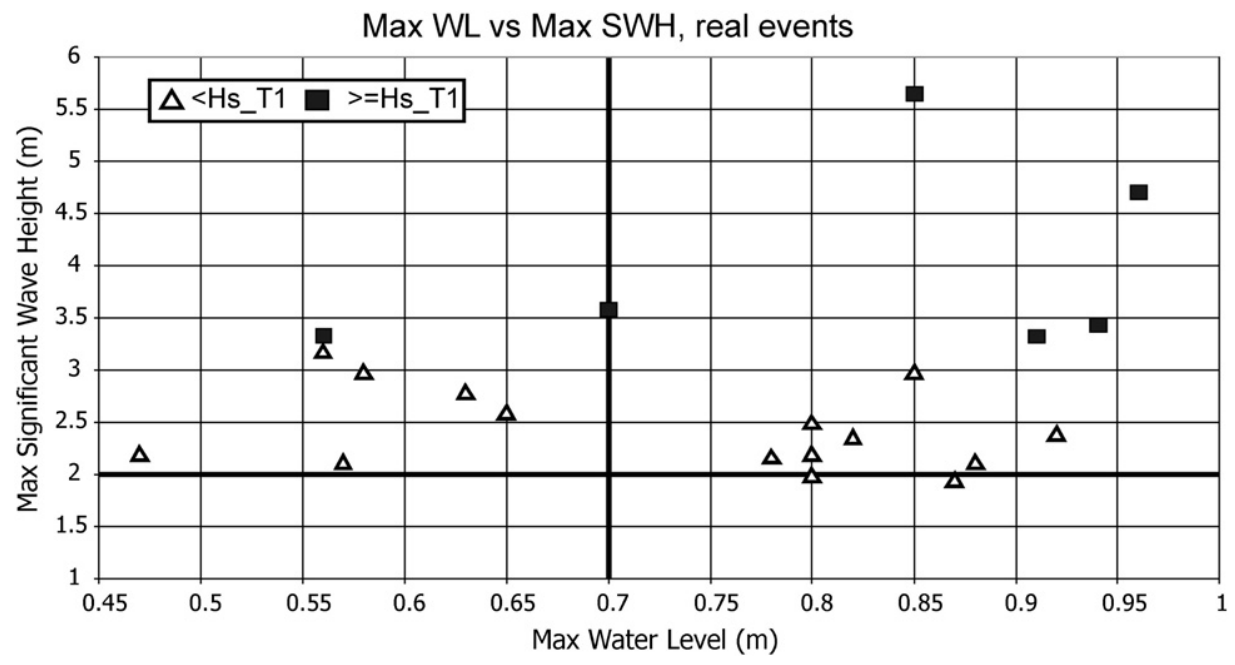

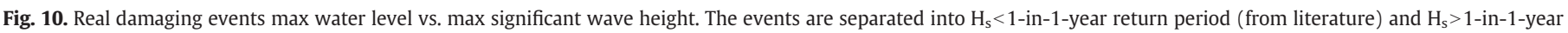
return period. The bold lines identify the two chosen thresholds. 


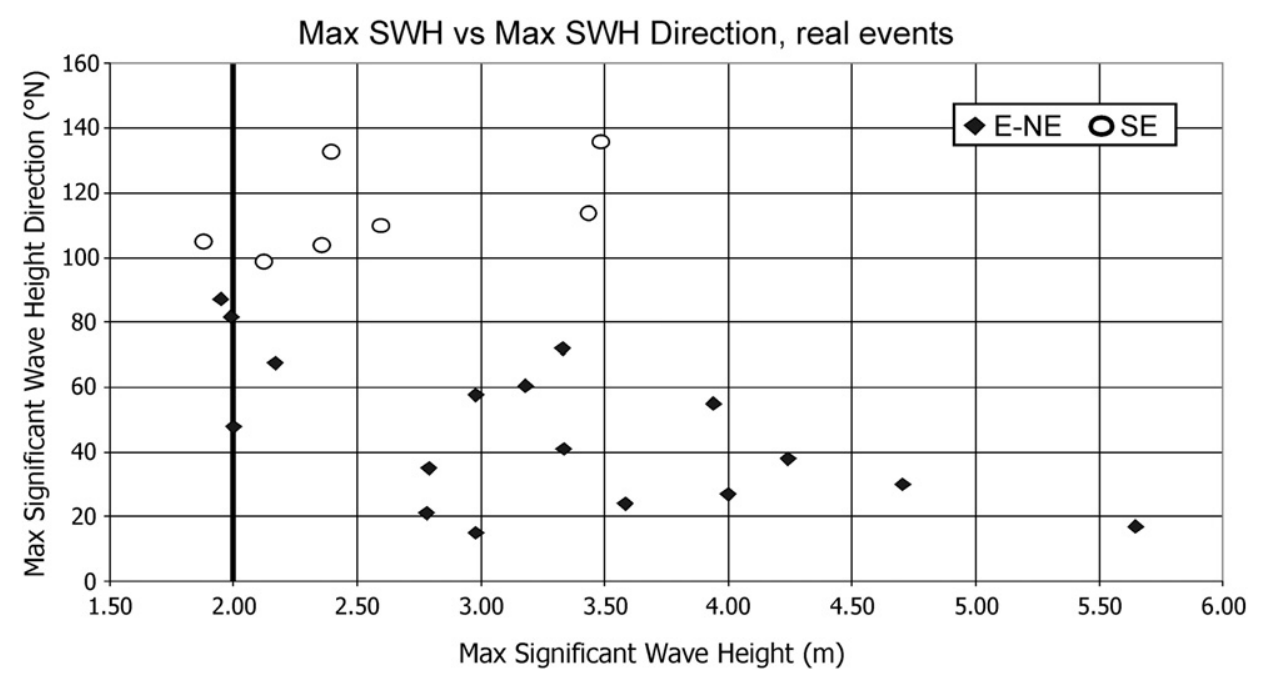

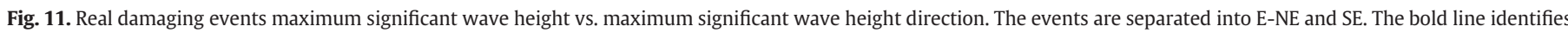
the chosen $\mathrm{H}_{\mathrm{s}}$ threshold.

Table 6

List of criteria used to define thresholds for each beach type and the chosen values.

\begin{tabular}{|c|c|c|c|c|}
\hline Beach type & Storm impact & Parameter & Thresholds & Criteria \\
\hline Natural with dunes & $\begin{array}{l}\text { Morphological change } \\
\text { (dune erosion/destruction) }\end{array}$ & $\begin{array}{l}\text { Wave height }\left(\mathrm{H}_{\mathrm{s}}\right) \\
\text { Water level (surge }+ \text { tide })\end{array}$ & $\begin{array}{l}\mathrm{T} 1 \mathrm{wave} \text { height }=3.3 \mathrm{~m} \\
\mathrm{~T} 1 \mathrm{WL}=0.85 \mathrm{~m} \text { above MSL }\end{array}$ & $\begin{array}{l}\text { DSF } \\
\text { (Dune Stability Factor) }\end{array}$ \\
\hline Anthropic & Inundation and damage to infrastructures & $\begin{array}{l}\text { Wave height }\left(\mathrm{H}_{\mathrm{s}}\right) \\
\text { Water level }(\text { surge }+ \text { tide })\end{array}$ & $\begin{array}{l}\mathrm{H}_{\mathrm{s}}=2.00 \mathrm{~m} \\
\mathrm{WL}=0.7 \mathrm{~m} \text { above MSL }\end{array}$ & $\begin{array}{l}\text { Comparison of "real" damaging } \\
\text { events (run-up + surge }+ \text { tide) } \\
\text { with max topographic elevation }\end{array}$ \\
\hline
\end{tabular}

does not account for profile response, which can only be studied using appropriate morphological models. Numerical models like S-Beach (Larson and Kraus, 1989) and X-Beach (Roelvink et al., 2009) are being tested at the study site (Van Dongeren et al., 2009; Harley et al., 2011). The profile models could account for beach and dune profile specificity such as sand characteristics, critical dune face slope for avalanching, profile evolution during the storms, etc.

Using numerical models the critical thresholds could be used to test profile response at a local and regional scale for assessment of post-storm emergency measures. This could be done in an off-line mode to support mapping of areas exposed to storm impacts. On the other hand, as the aims of the MICORE project include the setting up of an operational model chain to predict beach erosion and flooding, the knowledge of thresholds would optimise computational demands (e.g. models could be run only if forecasts exceed the thresholds).

\section{Acknowledgements}

The present paper is a contribution to the Project MICORE (Morphological Impact and COastal Risks induced by Extreme storm events) partially financed by the Commission of the European Communities within Framework VII, Environment and Climate Change theme (contract 202798). We are grateful to ISPRA and. C. Zumaglini of SIAP for providing wave and tide data and to ENI and CNR-ISMAR for providing wave data. The Lidar 2003 survey was kindly supplied by ENI. Field surveys were undertaken with help by M. Sedrati while GIS processing was done with the support of P. Luciani. We are grateful to M. Harley for the comments and review of the original manuscript. The paper was improved following suggestions of the journal's reviewers (N. Jackson and A. Sallenger) and the editing of the Associate Editor (A. Harvey).

\section{References}

Arena, G., Briganti, R., Corsini, S., Franco, L., 2001. The Italian wave measurement buoy network: 12 years management experience. Proc. 2nd Int. Conf. WAVES'01. ASCE S. Francisco, pp. 86-95.

Armaroli, C., Ciavola, P., 2011. Dynamics of a nearshore bar system in the northern Adriatic: a video-based morphological classification. Geomorphology 126, 201-216.

Armaroli, C., Ciavola, P., Caleffi, S., Gardelli, M., 2007a. Morphodynamics of nearshore rhythmic forms: an energy-based classification. Proceedings of 30th International Conference on Coastal Engineering: ASCE, 4, pp. 4009-4021.

Armaroli, C., Ciavola, P. Perini, L., Luciani, P., 2007b. Morfologia delle spiagge ravennati e vulnerabilità per fenomeni di inondazione. Terzo Forum Nazionale, Pianificazione e tutela del territorio costiero; questioni, metodi, esperienze a confronto, pp. 363-389 (in Italian).

Armaroli, C., Ciavola, P., Masina, M., Perini, L., 2009. Run-up computation behind emerged breakwaters for marine storm risk assessment. Journal of Coastal Research SI 56, 1612-1616.

Barnard, P.L., O' Reilly, B., Van Ormondt, M., Elias, E., Ruggiero, P., Erikson, Li, H., Hapke, C., Collins, B.D., Guza, R.T., Adams, P.N., Thomas, J., 2009. The framework of a coastal hazard model-a tool for predicting the impact of severe storms. Open-File Report, 2009-1073. USGS. 21 pp. http://pubs.Usgs.gov/of/2009/1073/.

Benavente, J., Del Río, L., Gracia, F.J., Martínez-Del-Pozo, J.A., 2006. Coastal flooding hazard related to storms and coastal evolution in Valdelagrana spit (Cadiz Bay Natural Park, SW Spain). Continental Shelf Research 26, 1061-1076.

Bernatchez, P., Fraser, C., Lefaivre, D., Dugas, S., 2011. Integrating anthropogenic factors, geomorphological indicators and local knowledge in the analysis of coastal flooding and erosion hazards. Ocean and Coastal Management 54, 621-632.

Bertotti, L., Cavaleri L., Tescaro N., 1996. Long term wave hindcast in the Adriatic Sea. Il Nuovo Cimento, 19 C, 1, 91-108.

Calabrese, L., Lorito, S., 2010. Mappatura della linea di riva da foto aerea. In: Perini, L., Calabrese, L. (Eds.), Il sistema mare-costa dell'Emilia-Romagna. Pendragon, Bologna, Italy, pp. 43-56.

Callaghan, D.P., Ranasinghe, R., Short, A., 2009. Quantifying the storm erosion hazard for coastal planning. Coastal Engineering 56, 90-93.

Canestrelli, P., Mandich, M., Pirazzoli, P.A., Tomasin, A., 2001. Wind, Depression and Seiches: Tidal Perturbations in Venice (1951-2000). Comune di Venezia, Centro Previsioni e Segnalazioni Maree, Venice, Italy. 105 pp.

Chaney, P.L., 2007. Storm overwash and the knickpoint effect: northwest Florida coast, USA. Journal of Coastal Research 23, 247-254.

Ciavola, P., Armaroli, C., 2010. Evoluzione recente del sistema dunale di Lido di DanteFoce Bevano (Ravenna): fattori naturali ed impatto antropico. Studi Costieri 17, 19-38 (in Italian) 
Ciavola, P., Armaroli, C., Perini, L., Luciani, P., 2007a. Evaluation of maximum storm wave run-up and surges along the Emilia-Romagna coastline (NE Italy): a step towards a risk zonation in support of local CZM strategies. Integrated Coastal Zone Management (ICZM)- the global challenge. Research Publishing Services, Singapore, pp. 505-516.

Ciavola, P., Armaroli, C., Chiggiato, J., Valentini, A., Deserti, M., Perini, L., Luciani, P. 2007b. Impact of storms along the coastline of Emilia-Romagna: the morphologica signature on the Ravenna coastline (Italy). Journal of Coastal Research SI 50, $540-544$.

Cipolla, F., Guzzetti, F., Lolli, O., Pagliacci, S., Sebastiani, C., Siccardi, F., 1999. Catalogo nazionale delle località colpite da frane e da inondazioni: verso un utilizzo più maturo dell'informazione. Proceedings of the Conference: Il Rischio Idrogeologico e la Difesa del Suolo. Accademia Nazionale dei Lincei, Rome, pp. 285-290 (in Italian).

Corsini, S., Inghilesi, R., Franco, L., Piscopia, R., 2004. Atlante delle onde nei mari italiani Italian wave atlas. Agenzia per la Protezione dell'Ambiente e per i Servizi Tecnic (APAT) and University of Rome " 3 ".

De Zolt, S., Lionello, P., Nuhu, A., Tomasin, A., 2006. The disastrous storm of 4 November 1966 on Italy. Natural Hazards and Earth System Sciences 6, 861-879.

Dolan, R., Davis, R.E., 1992. An intensity scale for Atlantic coast northeast storms. Journal of Coastal Research 8, 352-364

Ferreira, Ó., Garcia, T., Matias, A., Taborda, R., Dias, J.M.A., 2006. An integrated method for the determination of set-back lines for coastal erosion hazards on sandy shores. Continental Shelf Research 26, 1030-1044.

Froede Jr., C.R., 2006. The impact that Hurricane Ivan (September 16, 2004) made across Dauphin Island, Alabama. Journal of Coastal Research 22, 561-573.

Gardelli, M., Caleffi, S., Ciavola, P., 2007. Evoluzione morfodinamica della foce del torrente Bevano. Studi Costieri 13, 55-76 (in Italian).

Gares, P.A., 1990. Predicting flooding probability for beach dune systems. Environmental Management 14, 115-123.

Guzzetti, F., 2000. Landslide fatalities and evaluation of landslide risk in Italy. Engineering Geology 58, 89-107.

Guzzetti, F., Cipolla, F., Lolli, O., Pagliacci, S., Tonelli, G., 2002. An Information system on historical landslides and floods in Italy. Urban Hazards Forum. John Jay College, CUNY, New York

Hallemeier, R.J., Rhodes, P.E., 1988. Generic treatment of dune erosion for 100-year event. Proceedings of 21st Int. Conf. on Coastal Engineering. ASCE, New York, pp. 1197-1211.

Harley, M., Armaroli, C., Ciavola, P., 2011. Evaluation of XBeach predictions for a real-time warning system in Emilia-Romagna, Northern Italy. Journal of Coastal Research SI 64, 1861-1865.

Holman, R.A., 1986. Extreme value statistics for wave run-up on a natural beach. Coastal Engineering 9, 477-491.

Houser, C., Hamilton, S., 2009. Sensitivity of post-hurricane beach and dune recovery to event frequency. Earth Surface Processes and Landforms 34, 613-628.

Houtenbos, A.P.E.M., Hounjet, M.W.A., Barends, B.J., 2005. Subsidence from geodetic measurements in the Ravenna area. Proceedings of the 7th International Symposium on Land Subsidence (Shanghai, China), pp. 79-99.

IDROSER, 1996. Progetto di Piano per la difesa del mare e la riqualificazione ambientale del litorale della Regione Emilia-Romagna. Regione Emilia-Romagna, Bologna, Italy. 365 pp.

Jiménez, J.A., Ciavola, P., Balouin, Y., Armaroli, C., Bosom, E., Gervais, M., 2009. Geomorphic coastal vulnerability to storms in microtidal fetch-limited environments: application to NW Mediterranean \& N Adriatic Seas. Journal of Coastal Research SI 56, 1641-1645.

Judge, E.K., Overton, M.F., Fisher, J.S., 2003. Vulnerability indicators for coastal dunes. Journal of Waterway, Port, Coastal, and Ocean Engineering 129, 270-278.

Komar, 1998. Beach Processes and Sedimentation. Prentice Hall, NJ. 544 pp.

Kriebel, D.L., Dalrymple, R., Pratt, A., Sakovich, V., 1997. A Shoreline Risk Index for Northeasters. Proceedings of ASCE Int. Conf. on Natural Disaster Reduction, ASCE New York. 251-252.

Larson, M., Kraus, N.C., 1989. SBEACH: Numerical Model for Simulating Storm-Induced Beach Change. CERC-89-9. US Army Corps of Engineers, Vicksburg.

Lionello, P., 2005. Extreme surges in the Gulf of Venice. Present and future climate. In: Fletcher, C., Spencer, T. (Eds.), Venice and its lagoon, state of knowledge. Cambridge University Press, Cambridge UK, pp. 59-65.

Lorito, S., Calabrese, L., Perini, L., Cibin, U., 2010. Uso del suolo della costa. In: Perini, L., Calabrese, L. (Eds.), Il sistema mare-costa dell'Emilia-Romagna. Pendragon, Bologna, Italy, pp. 109-118.

Masina, M., Ciavola, P., 2011. Analisi dei livelli marini estremi e delle acque alte lungo il litorale ravennate. Studi Costieri 18, 84-98 (in Italian).

Masselink, G., Short, A.D., 1993. The effect of tide range on beach morphodynamics. Journal of Coastal Research 9, 785-800.
Mendoza, E.T., Jimenez, J.A., 2004. Factors controlling vulnerability to storm impacts along the Catalonian coast. Proceedings International Conference of Coastal Engineering 2004, Lisbon, pp. 3087-3099.

Mendoza, E.T., Jiménez, J.A., 2006. Storm induced beach erosion potential on the Catalonian coast. Journal of Coastal Research SI 48, 81-88.

Perini, L., Calabrese, L., 2010. Le dune costiere dell'Emilia-Romagna: strumenti di analisi, cartografia ed evoluzione. Studi Costieri 17, 71-84 (in Italian).

Plant, N.G., Stockdon, H.F., Sallenger, A.H., Turco, M.J., East, J.W., Taylor, A.A., Shaffer, W.A., 2010. Forecasting hurricane impact on coastal topography. Eos 91, 65-66.

Pompe, J.J., Rinehart, J.R., 2008. Mitigating damage costs from hurricane strikes along the southeastern U.S. Coast: a role for insurance markets. Ocean and Coastal Management 51, 782-788.

Pye, K., Blott, S.J., 2008. Decadal-scale variation in dune erosion and accretion rates: an investigation of the significance of changing storm tide frequency and magnitude on the Sefton coast, UK. Geomorphology 102, 652-666.

Robertson, W.V., Zhang, K., Whitman, D., 2007. Hurricane-induced beach change derived from airborne laser measurements near Panama City, Florida. Marine Geology 237, 191-205.

Roelvink, J.A., van Reniers, A., Dongeren, A., van Thiel de Vries, J., McCall, R., Lescinski, J., 2009. Modeling storm impacts on beaches, dunes and barrier islands. Coastal Engineering 56, 1133-1152.

Ruggiero, P., Komar, P.D., McDougal, W.G., Marra, J.., Beach, R.A. 2001. Wave runup. Extreme water levels and erosion of properties backing beaches. Journal of Coastal Research 17, 407-419.

Ruz, M.H., Meur-Ferec, C., 2004. Influence of high water levels on aeolian sand transport: upper beach/dune evolution on a macrotidal coast, Wissant Bay, northern France. Geomorphology 60, 73-87.

Sallenger, A.H., 2000. Storm impact scale for barrier islands. Journal of Coastal Research $16,890-895$.

Sedrati, M., Ciavola, P., Reyns, J., 2008. Swash bar behaviour on a protected microtidal beach: Lido di Dante, Italy. Proceedings 3rd International Short Conference/Course on Applied Coastal Research. Nuova Editoriale Bios, Lecce, pp. 153-164.

Sedrati, M., Ciavola, P., Reyns, J., Armaroli, C., Sipka, V., 2009. Morphodynamics of a microtidal protected beach during low wave-energy conditions. Journal of Coastal Research SI 56, 198-202.

Short, A.D., Hesp, P.A., 1982. Wave, beach and dune interactions in southeastern Australia. Marine Geology 48, 259-284.

Signell, R.P., Chiggiato, J., Horstmann, J., Doyle, J.D., Pullen, J., Askari, F., 2010. Highresolution mapping of Bora winds in the northern Adriatic Sea using Synthetic Aperture Radar. Journal of Geophysical Research 115, C04020. doi:10.1029/ 2009JC005524.

Stockdon, H.F., Holman, R.A., Howd, P.A., Sallenger Jr., A.H., 2006. Empirical parameterization of setup, swash, and runup. Coastal Engineering 53, 573-588.

Stockdon, H.F., Sallenger, A.H., Holman, R.A., Howd, P.A., 2007. A simple model for the spatially-variable coastal response to hurricanes. Marine Geology 238, 1-20.

Teatini, P., Ferronato, M., Gambolati, G., Bertoni, W., Gonella, M., 2005. A century of land subsidence in Ravenna, Italy. Environmental Geology 47, 831-846.

Valentini, A., Delli Passeri, L., Paccagnella, T., Patruno, P., Marsigli, C., Deserti, M., Chiggiato, J., Tibaldi, S., 2007. The Sea State forecast system of ARPA-SIM. Bollettino di Geofisica Teorica ed Applicata 48, 333-349.

Van Dongeren, A., Bolle, A., Vousdoukas, M.I., Plomaritis, T., Eftimova, P., Williams, J., Armaroli, A., Idier, D., Van Geer, P., Van Thiel De Vries, J., Haerens, P., Taborda, R., Benavente, J., Trifonova, E., Ciavola, P., Balouin, Y., Roelvink, D., 2009. MICORE: dune erosion and overwash model validation with data from nine European field sites. Proceedings of Coastal Dynamics 2009, Tokyo, Japan, pp. 1-15.

Vellinga, P., 1982. Beach and dune erosion during storm surge. Coastal Engineering 6, 361-387.

Vellinga, P., 1986. Beach and dune erosion during storm surges. Ph.D. Thesis, Delft University of Technology; also: WL| Delft Hydraulics report no. 372, December 1986

Wang, P., Kirby, J.H., Haber, J.D., Horwitz, M.H., Knorr, P.O., Krock, J.R., 2006. Morphological and sedimentological impacts of Hurricane Ivan and immediate poststorm beach recovery along the northwestern Florida barrier-island coasts. Journal of Coastal Research 22, 1382-1402.

Wright, L.D., Short, A.D., 1984. Morphodynamic variability of surf zones and beaches: a synthesis. Marine Geology 56, 93-118.

Yu, C.S., Decouttere, C., Berlamont, J., 1998. Storm surge simulations in the Adriatic Sea. CENAS. Kluwer Academic, Dordrecht, The Netherlands, pp. 207-232.

Zhang, K., Douglas, B.C., Leatherman, S., 2001. Beach erosion potential for severe Nor'easters. Journal of Coastal Research 17, 309-321. 